\title{
STUDIES OF THE ROOT SYSTEM OF COFFEA ARABICA L. \\ Part I.-Environmental Condition Affecting the Distribution of Coffee Roots in Coloso Clay
}

\author{
By J. Guiscafré-Arrillaga and Luis A. Gómez
}

\section{INTRODUCTION}

To the present, the aerial portion of plants have been more intensively and thoroughly studied in botanical and agronomic problems. The reasons for this are obvious, among the most important being that it is the part from which man usually derives more income and the easier on which to undertake investigations.

However, knowing that production in the tops of plants depend on the roots and particular environmental soil conditions it is clear that studies of the root system help a great deal the technologist and agronomist in the efficient performance of agricultural practices, such as systems and distances for planting, fertilizer application, general tillage operations, drainage and irrigation systems, control of diseases and erosion, intercropping and others of special application to particular crops, all of which contribute to a more productive aerial portion.

With these objectives in view and to obtain fundamental knowledge on which to base investigations and recommendations for necessary agricultural practices in the growing of coffee, this study was undertaken.

\section{Literature Review}

The distribution of roots of erop plants in the soil and related problems have been studied by Gómez (1), Lee (2), Lee and Bissinber (3), Nutman (4), (5), (6), Trench (7), Venkatraman (8), Weaver (9), Weaver and Christ (10). These investigators have devised and used various methods for the most accurate determination of the root system under study. Such methods may be classified as natural and artificial. Those methods in which specially designed boxes or cylinders are used for growing the plant the root system of which is to be studied, may be termed as artificial while the methods of excavating and weighing the roots of plants as they actually occur at different soil depths, or that of exposing and fol- 
lowing the roots by washing with jets of water or loosening the soil with hand tools and drawing the root system to scale in the field, may be classified as natural.

The artificial method: This has been used by Lee (2) and Venkatraman (8). The method followed by Lee (1) consisted in planting gsuar cane seeds in boxes with detachable sides and poultry neting wire placed horizontally and filled up with soil at different depths. Once the plants had attained the desirable size, the soil was washed away and the roots exposed but held in their correct position by the horizontally placed poultry netting. In this way the distribution of the roots at different depths was determined. Lee (2) originated a more natural and accurate method later.

Venkatraman (8) used earthenware cylinders in which cane seeds were planted for studying the root distribution.

Natural methods: The following investigators have used the "natural methods" for the study of root systems of plants: Lee (2), (3), Gómez (1), Nutman (4), (5), (6), Trench (7) and Weaver et al. (9), (10).

The method used by Lee (2), Lee and Bissinger (3), while making studies of the root distribution of sugar cane in Hawaii and the Philippine Islands may be described as follows: after selecting 5 to 10 stools as uniform as possible in a commercial field, the cane is cut and the green and dry weights of the tops determined. Stakes are set exactly half way between the rows of cane to be studied and the contiguous rows on both sides. A cord is stretched around the four stakes enclosing the cane stools under study. Then the excavation is begun within this area and all soil removed to a depth of 8 inches care being taken that the excavation does not exceed 8 inches in depth. As the earth is removed from the area studied, it is thrown in a wire screen of $1 / 4$-inch mesh placed at one side of the excavation. The screen separates the roots from the soil. All the roots found in the top-most 8-inch layer represent the mass of roots of the 5 or 10 stools in the top-most 8 inches of soil. The roots from the top-most 8-inch layer are then collected in bags, labelled and held until the complete excavation has been made. Deeper excavations are then started and the roots separated for every 8-inch layer until the desired depth is attained, which is usually that point where the quantity of roots found is negligible. The roots from the various soil levels are then washed, separately air-dried, and oven dried, until all mo:sture is removed and weighed. 
Following this method which is very accurate, the distribution of roots at various soil depths is determined with certainty. Lee (2), (3), prefers this quantitative method to the expensive, and almost impossible task of longitudinal measurements since the weights of roots may possibly be even better index of the absorbing surfaces.

Gómez (1) followed Lee's method for the study of the distribution of sugar-cane roots in certain soil types of Puerto Rico.

Nutman (4), (5), (6) has studied the root system of coffee, Coffee arabica L., in various soil types of British East Africa using various methods.

Where water was readily available Nutman studied the root system of coffee by washing the soil with fine jets of water under pressure. The soil was washed in layers and the roots exposed and followed to their terminations. The roots were pegged in their position on the soil face by means of long, pointed steel rods. When the roots of the whole selected sector were washed out, and the roots pegged in their natural positions a string grid of $1 \mathrm{ft}$. mesh was then erected and the root system drawn to scale in the field. Where water was not available, excavation was performed by hand with the help of hammers and chisels.

But Nutman (6) used furthermore the following method which he claims to be more accurate. This consists in digging a trench with one face 8 to 9 inches from the trunk of each experimental tree. The soil is then washed away in adequately measured $1 \mathrm{ft}$. cubes by a jet of water of $1 / 2$ inch diameter and 10 pounds of pressure. The soil washed is examined and all roots from each cube are collected, washed, labelled and preserved. Then all the feeding roots are measured from a selected section of the root system. In this way it is determined by trees the distribution of the feeding area at various soil depths.

In addition Nutman (5) has studied the effect on the coffee root system of various soil conditions, such as presence of hardpans, aeration, height of the water table, soil reaction, manurial treatments and cultivation methods.

Trench (7) after studying the root system of coffee trees in Kenya carefully removed by washing, comments that the root system of coffee can be materially affected by environmental factors and that it ean be modified by wise guidance and suitable treatments for proper development.

In the United States of America, Weaver and his associate (9), (10) have studied intensively the root systems of numerous plants 




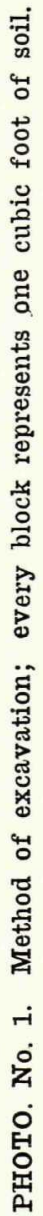


in various regions of that country. His method consists in working into the side of a trench with hand tools and folowing up the roots by breaking away the soil. Once exposed, the entire root system is drawn to scale in the field.

After a critical study of the work done and the results accomplished by the investigators just mentioned, the writers developed a new method which is really an oulgrowth of the methods developed by Lee (2), (3), Gómez (1) and Nutman (6) but which is thought to be more adaptable for the study of the root system of coffee in our prevailing soil and climatic conditions.

Before going into the details of the method used in this preliminary study, an account will be given of the conditions of the trees studied and their environment.

\section{Conditions Relative to the Soll and Coffee Trees Studied on a Representative Solm Type of Puerto Rico}

The six coffee trees selected for this study were located at the farm of the College of Agriculture and Mechanic Arts at Mayagüez, P. R.

These trees were growing in a 2-acre terrace of soil belonging to the Coloso Clay type and surrounded on two sides by a small stream and hills of low elevation of Catalina Clay. The Coloso Clay found in this terrace originated from alluvial and colluvial deposition of the stream and the neighboring hills. Terraces of this nature and soil type are quite abundant in the coffee region of the island. The drainage of this soil is poor during the rainy season due to the high level of the water table. This soil has been found to be quite productive when proper drainage systems are made. The physical and chemical analyses of this type of soil are shown in tables III and IV. The average annual rainfall for this region is 81 inches.

The six coffee trees used for this study were 7 years old. The average size of these trees was $299.16 \mathrm{cms}$. high, $159.66 \mathrm{cms}$. wide and of a trunk diameter of $3.70 \mathrm{cms}$. The individual sizes of all trees is shown in table VIII. The general vegetable conditions of the trees is shown by tree No. 6 in plate 3 . All the trees studied belong to the arabian coffee type, Coffea arabica L., which is the coffee variety extensively planted in the island.

The general conditions of the field where the excavation was performed may be described as follows: The coffee trees were planted systemaiically in rows at $8 \mathrm{ft} \times 8 \mathrm{ft}$. under leguminous shade trees 
of "guaba", Inga Inga (L.) Britton, and "guamá", Inga laurina (Sw.) Willd., planted at an approximate distance of $16 \mathrm{ft}$. $\times 16 \mathrm{ft}$. The agricultural operations effected rearly consisted in weeding with a "machete" two or three times, and pruning the shade lightly after picking the crop. No fertilizer was ever applied to the trees in this field.

The excavations of the root system were started on February of 1937 and finished on May of the same year. The trees were in bloom when the tops were cut off.

\section{Method of Procedure}

For this study, six contiguous trees were selected in one of the innermost rows of the field. The tops were cut close to the soil surface and the green weights of the stems, leaves and lateral branches were obtained by direct weighing in the field. The dry weights of these same parts were obtained later after drying in the sun and in electric ovens. Table VIII shows the green and dry weights of each tree.

Once the tops were removed, stakes were placed halfway between the row of coffee trees to be studied and the neighboring rows on both sides. A cord was stretched around these stakes thus marking a total area of 384 sq. ft. equivalent to an area of 64 sq. ft. corresponding to each of the six trees. The posiiion of the stakes, the top-most total area excavated and the planting distance of the trees is shown in text figure No. 1.

The area corresponding to each tree was then divided in squares of one sq. ft. each by means of 5-inch nails and cords. The excavation was begun, and the soil was removed in blocks of exactly one cubic foot in the $64 \mathrm{sq}$. ft. area corresponding to each tree. The depth of excavation was carefully checked with a 12 -inch hand ruler. The roots found in each cubic foot excavated per tree and per layer were separated from the soil by a wire screen of $1 / 4$ inch mesh and by hand. The roots found were collected in cloth bags and taken to the laboratory where they were washed and spreaded under shade until the excess of water was evaporated. Then the green weights were determined. Afterwards the roots found in each cubic foot were dried in electric ovens to deiermine the dry weights. The same was done with a second layer to a depth of 24 inches, with a third layer to a depth of 36 inches, and to a fourth layer to a depth of 48 inches, in which layer the amount of roots found was very small. Details 
concerning the excavation and separation of the roots from the soil are shown by plates Nos. 1 and 2 .

The excavation by cubic foot was controlled by an excavation map specially prepared for the total area to be excavated for each tree, by numbering each block. The excavation map of the root system of the six trees used for the four layers excavated by blocks of one cubic foot each is shown in text figures Nos. 3, 4, 5, 6, 7 and 8 .

It was possible to make the excavations by blocks of one cubic foot due to the stiffness of the clay contained in the soil. It is realized that in loose soils this method is impracticable, but it is claimed to be the most accurate method for the study of root systems in clay soils because it makes possible to determine not only the quantities of roots at different soil depths but also the distribution of the roots in definite lateral areas. In other words, this method determines the lateral spread as well as the vertical penetration of the roots studied.

It is expected that some of the roots of the trees under study have extended on both sides beyond the excavations limits, but in a field planted at uniform distances, the loss of roots beyond the limits of the excavation are compensated by the roots of the trees of the neighboring rows which extend into the excavation. This idea advanced by Lee (2), (3) is applicable to systematic root studies in fields planted out at uniform distances; the types of field that should be used in studies of this nature.

The two major handicaps in the execution of this study were, the search for a systematic plantation, which are still few in the island and the separation of the coffee roots from the roots of neighboring shade rtees, as all coffee is grown under shade in Puerto Rico. This separation was possible by a thorough study, previous to the excavation of the rot systems under study, of the roots of coffee, and the shade irees in the vicinity. The morphology, color and odor of the coffee roots is typical, but in order to avoid any errors, as the separation of the roots from the soil was done by laborers, the roots found in each cubic foot excavated were thoroughly inspected by the writers and the roots of the shade trees discarded.

The writers also admit that the green weights of the roots are not completely accurate. There is the possibility for some water to be lost, thru the necessary handling during the excavation, separation and weighing, but if care is taken to perform under shade all the operations involved in the excavation, separation, washing and drying until the excess of water brought in by the washing is re- 
234 THE JOURNAL OF AGRICULTURE OF THE UNIVERSITY OF P. R.

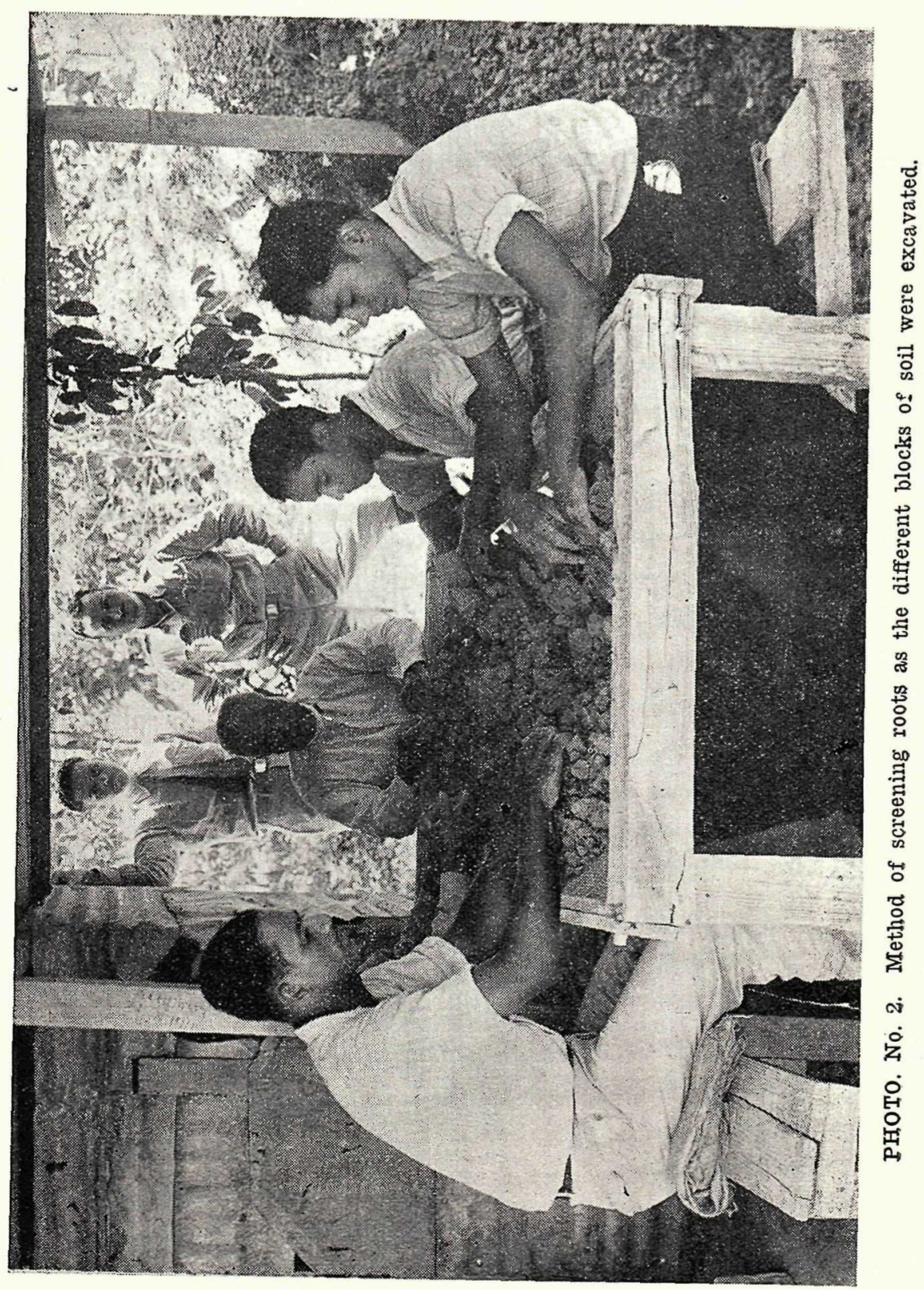


moved, it most be realized that there is accuracy in the method used for the determination of the green weights. Although before starting the study, the difficulty involved in the determination of the green weights of the roots was appreciated these were obtained in order to compare the ratios of tops to roots based on the green and dry weights of both parts of the trees.

\section{Results}

NINETY-FOUR PERCENT OF THE COFFEE ROOTS WERE FOUND IN THE TOP-MOST 12 INCHES OF SOIL:

That 94 percent of the roots were present in the top-most 12 inches af soil is shown by the following tables I and II in which the greatest quantity of roots of each of the six trees was found in the top-most 12 inches of soil.

The quantity of roots decreases tremendously from the 12-inch. level downward to the depth of 48 inches at which the quantity of roots found was negligible. A small amount of roots was found for trees Nos. 3 and 6 at a depth of 48 inches. According to the figures, it is shown that 94 percent of all rots was found in the topmost 12 inches and that practically the whole root system of sevenyear old coffee trees growing in Coloso Clay is found in the first 24 inches of soil, since 99 percent of all the roots of the six trees under study were excavated above the 24-inch level. (see Photos. 4 and 5.)

\section{THE PERCENTAGE OF ORGANIC MATTER IS HIGH IN THE}

COLOSO CLAY TOP-SOILS :

There was 2 percent of organic matter in the top-most 12 inches of soil as indicated by table III. This is remarkably high for Puerto Rican soils. The quantity of organic matter decreases tremendously at lower depths. The high content of organic matter in the first layer is undoubtly due to the acumulation of leaves and other vegetable remains of the coffee, shade trees and weeds. The high content of organic matter may have a direct influence on the development of more roots at the surface, although the effect of better aeration of surface layers is also a factor to be considered.

As shown also by table III, the percentages of silt and clay was practically the same at all soil levels while the percentage of total sand was greater at the 36 and 48 inch level.

The high percentage of clay, and average of 72 percent, makes this a distinctly clay soil. 

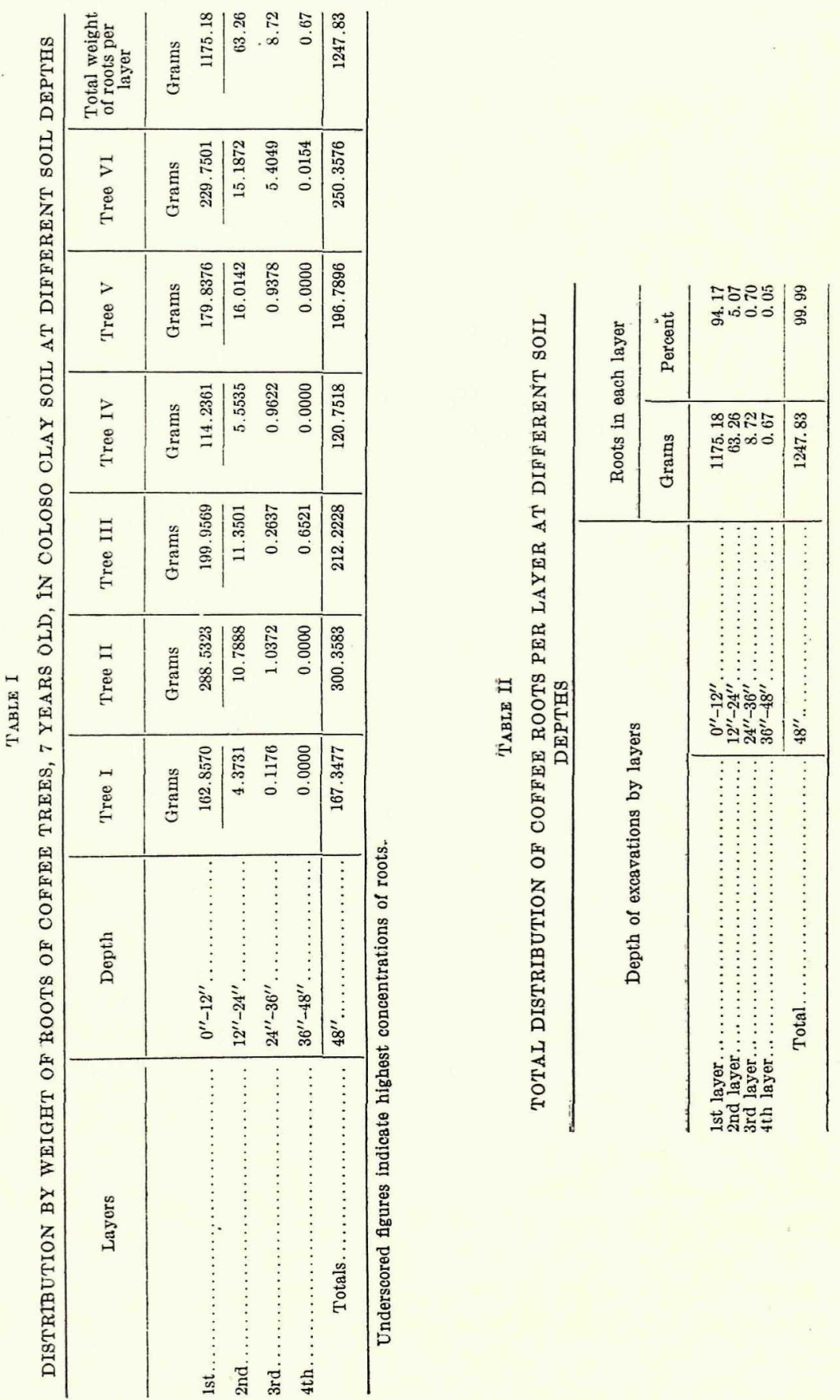
STUDIES OF THE ROOY SYSTEM OF COFFEE ARABICA L. 237
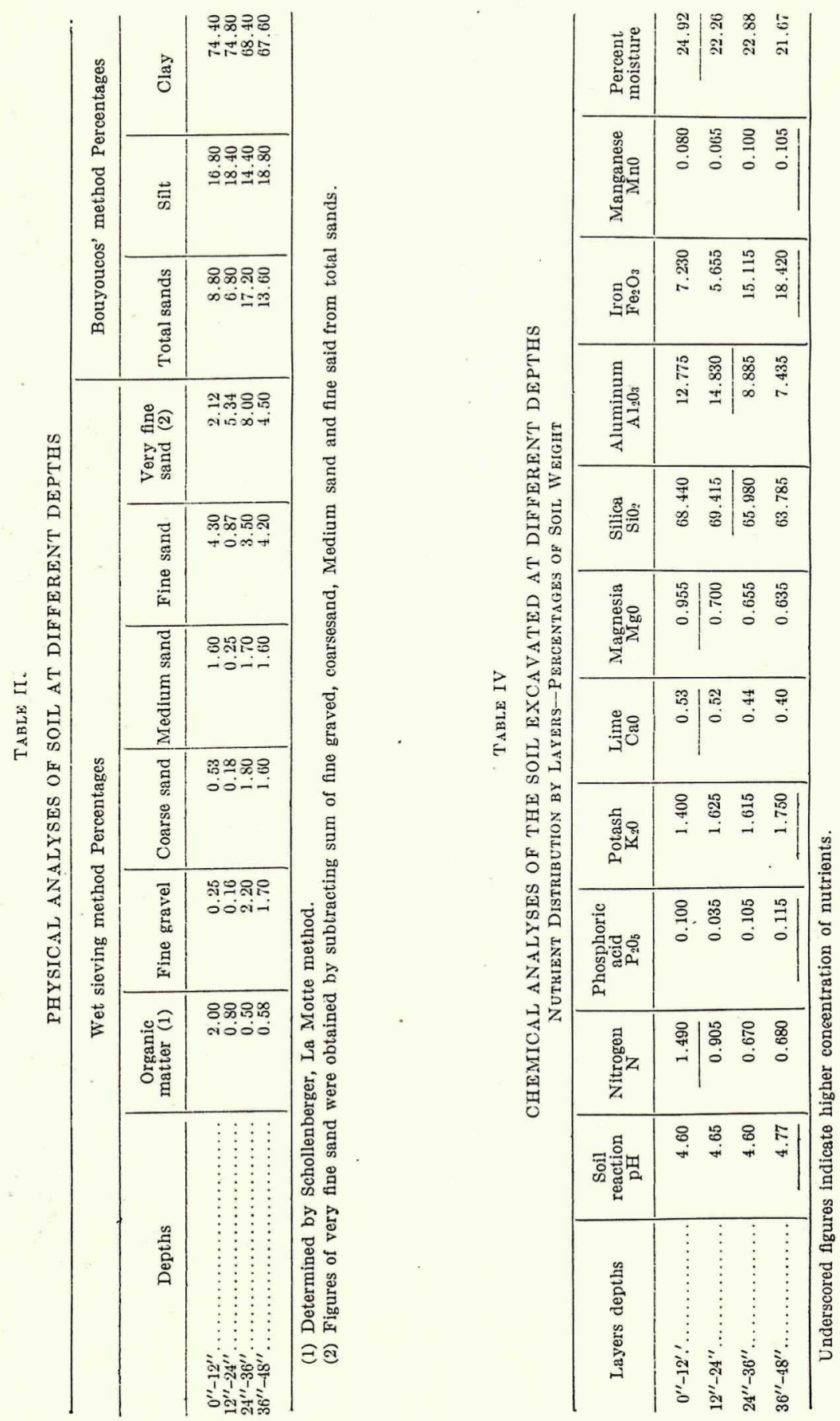


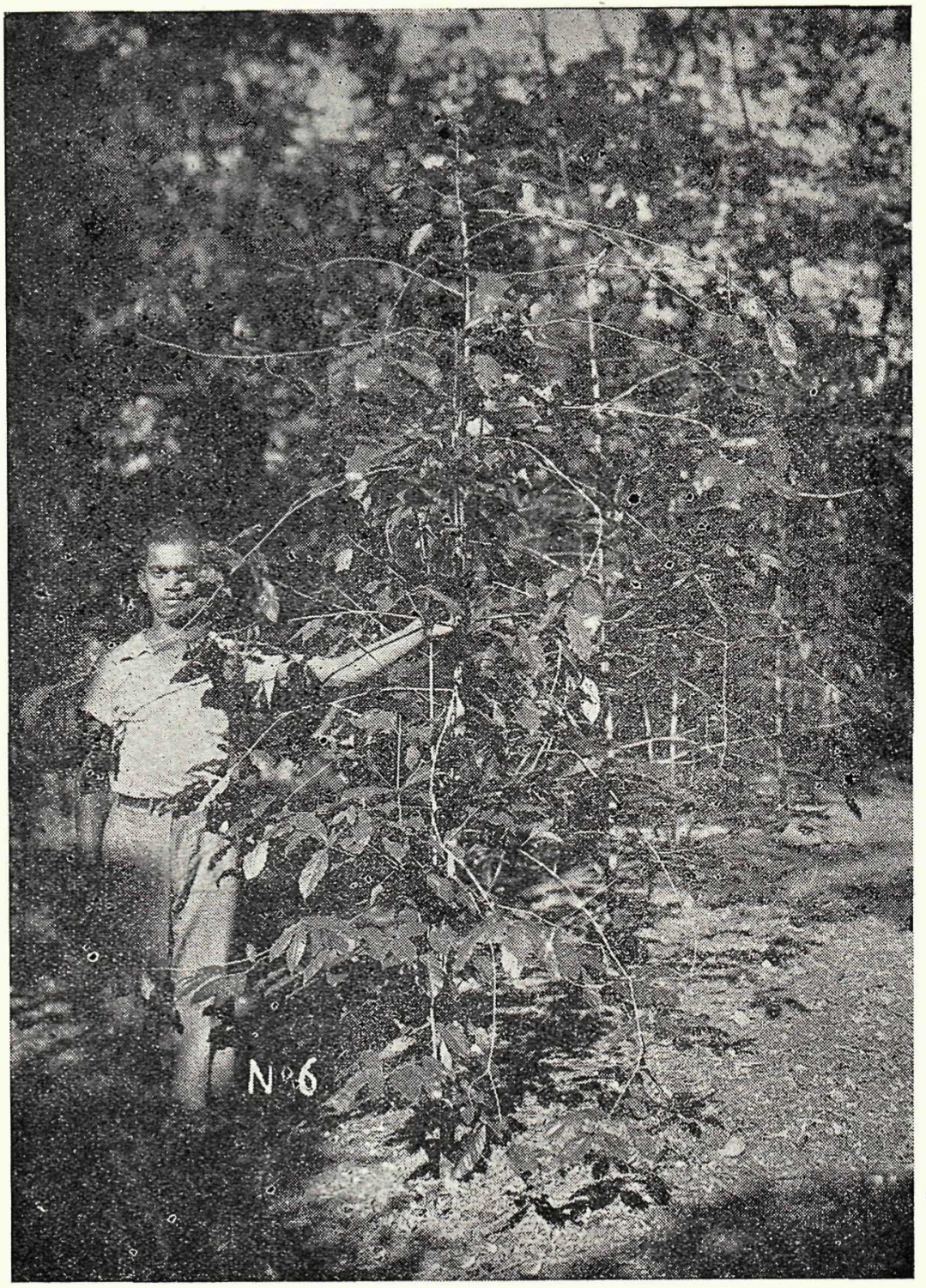

PHOTO No. 3. The size and vegetative conditions of one of the six trees studied. 
THE PRINCIPAI, PLANT NUTRIENTS ARE PRESENT IN FAVOR.IBLE GUANTITIES AT THE SOIL LEIELS STUDIEI):

Upon examination, table IV shows that the nitrogen and potash are present in rather high yantities, while phosphorus is present in low quantities. The quan'ity of these three nutrients is practically the same at all depths.

The $\mathrm{pH}$, on the average 4.6, indicaies that the soil reaction is decidely acid. The content of calcitim was extremely low and as well as the $\mathrm{pH}$, was practically the same for all soil levels. The iron was present in higher quantities at the 36 and 48 -inch levels while alumninum was present in lower amounts at these same levels.

The percentage of moisture alihough higher at the first layer was practically the same at all the other soil levels studied.

Magnesia is present at all soil depths in greater quantities than calcium.

In general, accoiding to the chemical analysis shown by table IV, the Coloso Clay is a good soil. It has proved to be productive for sugar cane growing specially in dry years and when using the "gran banco" system of planting which provides adequate conditions of: drainage.

In text figure 2 the distribution of the coffee root system is shown in relation to the root weight and physical and chemical soil analyses of the different soil layers.

A HEAVY TOP IS NOT DEPENDENT ON I STRONG AND HEAVY ROOT SYSTEM :

In tables $\mathrm{V}$ and $\mathrm{VI}$ is shown the arlvantages of the new method used for this study.

In table $\mathrm{V}$, in the first layer, of the $384 \mathrm{cu}$. ft. excavated for the six trees, only $242 \mathrm{cu}$. ft. were found with roots and the number of cubic feet found with roots decreased enormously in the other three layers. In the fourth layer, of $384 \mathrm{cu}$. ft. excavated, only $4 \mathrm{cu}$. ft. were found with roots and these belonged to the root systems of trees Nos. 3 and 6 . Text figures 3 to 8 show the advantages still more clearly since in the excavation maps for each tree, the lateral extension and vertical penetraion of the roots is indicated by the dry weights of the roots found in cach eubic foot excavated. Upon examination, each individual excaration map shown in text figures 3 to 8 , gives an aproximate idea of the form of the root 


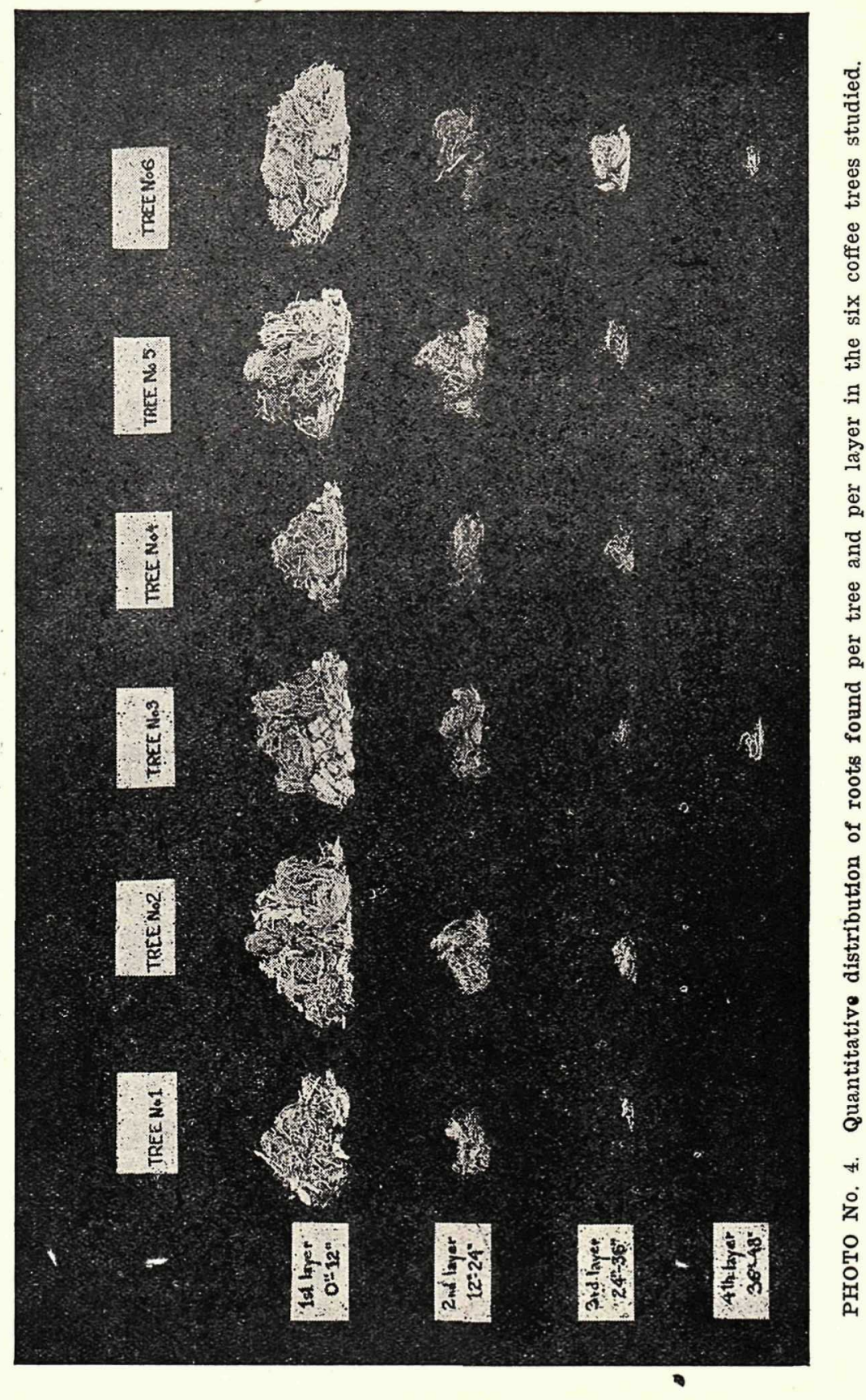




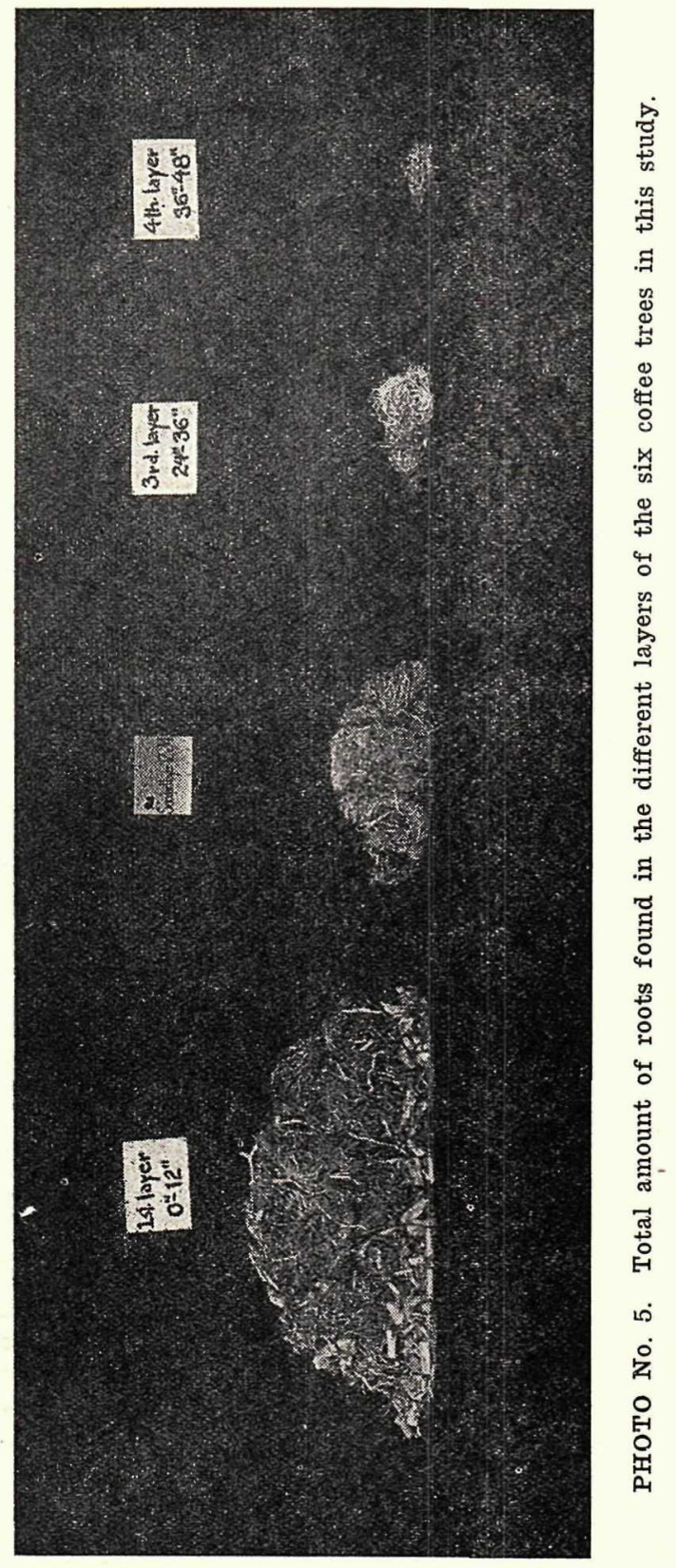


system of each 7-year-old coffee tree in this type of soil. According to the dry weight of roots found per cubic foot per tree and to the position of the blocks of soil found with roots, the form of the root system is that of an inverted cone of rather short height. It is also shown in text figures 2 to 8 that the vertical penetration of the root system is 4 feet and the lateral extension is approximately 4 feet also.

TABLE V

DISTRIBUTION OF ROOTS AT DIFFERENT SOIL DEPTHS IN RELATION TO TOTAL VOLUME OF SOIL EXCAVATED AND TO VOLUME OF SOIL WHERE ROOTS WERE PRESENT

QUantities of Roots, DRY Weights

\begin{tabular}{|c|c|c|c|c|c|}
\hline Layer depths & $\begin{array}{l}\text { Total weight } \\
\text { of roots per } \\
\text { layer of six } \\
\text { coffee trees }\end{array}$ & $\begin{array}{l}\text { Total cubic } \\
\text { feet excavated } \\
\text { per layer }\end{array}$ & $\begin{array}{c}\text { Weight of roots } \\
\text { per layer per } \\
\text { cubic foot }\end{array}$ & $\begin{array}{l}\text { Cubic feet } \\
\text { excavated } \\
\text { where roots } \\
\text { were found }\end{array}$ & $\begin{array}{l}\text { Weight of root } \\
\text { per cubic foot } \\
\text { where roots } \\
\text { were found }\end{array}$ \\
\hline . & Grams & & Grams & & Grams \\
\hline 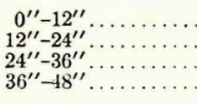 & $\begin{array}{r}1175.18 \\
63.26 \\
8.72 \\
0.67\end{array}$ & $\begin{array}{l}384 \\
384 \\
384 \\
384 \\
\end{array}$ & $\begin{array}{l}3.060 \\
0.140 \\
0.020 \\
0.002 \\
\end{array}$ & $\begin{array}{r}242 \\
103 \\
35 \\
4 \\
\end{array}$ & $\begin{array}{l}4.86 \\
0.61 \\
0.32 \\
0.17 \\
\end{array}$ \\
\hline Total. & 1247.83 & 1536 & .. & 384 & \\
\hline
\end{tabular}

In table VI, is shown that of a total of $256 \mathrm{cu}$. ft. excavated for each of the six trees studied, the number of one cubic foot blocks containing roots fluctuate between 51 and 76 blocks.

The trees with the heaviest root systems, Nos. 2 and 6, do not have the most extensive root systems since all their roots were found in 65 and 57 one-cu. ft blocks respectively. If table 8 shown later is examined, it will be noticed ihat trees Nos. 2 and 6 do not possess the heaviest iops.

TABLE VI

WEIGHT OF ROOTS PER CUBIC FOOT OF SOIL PER TREE

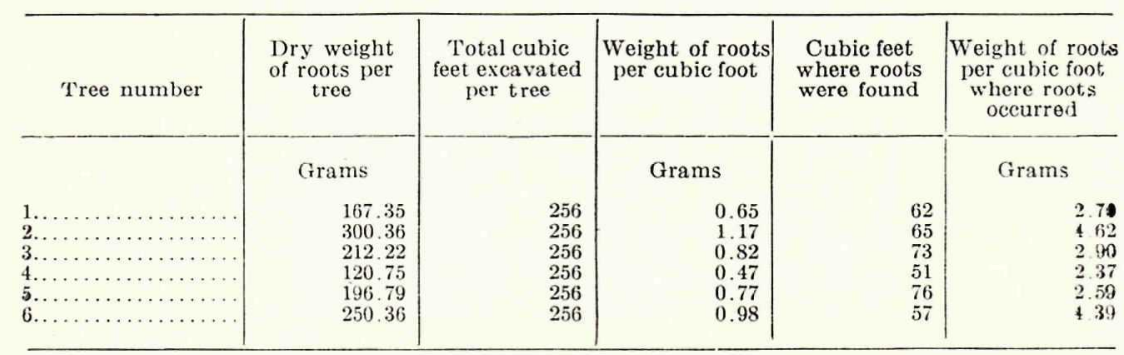


With the exception of tree No 4 the figures for the dry weights of tops and roots and number and position of the one-cubic foot blocks excavated for each tree found with roots, indicate that a heavy top growth is not dependent on a heavy and extensive root system. This is in accord with Lee's (2), (3) and Gómez (1) investigations on the root systems of sugar cane in Hawaii, the Philippine Islands and Puerto Rico.

THERE IS NO FIXED RATIO OF TOPS TO ROOTS IN COFFEE TREES:

Studying the figures for green and dry weights of tops to roots ratio since it is different for all the six trees studied. Based on the total dry weights of the tops and roots of all trees, the ratio of tops to roots ratio is 7 . Inasmuch as these figures are practically equivalent it may be stated that the ratio of tops to roots is aproximately 8 , taking in consideration either the dry or green weights of both parts of 7-year-old coffee trees.

In table VII information is given also regarding fertilizer applications and moisture conditions of the six trees studied.

THE TRUNK DIAMETER OF COFFEE TREES IS A GOOD INDICATION OF A HEAVY TOP AND A STRONG ROOT SYSTEM :

In order to understand clearly the possible interrelationships between certain botanical characteristics of the tops and roots of the 1rees studied, table VIII was prepared.

This table shows the following :

(a) That the average tree size for the trees used in this itudy has a height of $299.16 \mathrm{cms}$., almost $10 \mathrm{ft}$; $159.66 \mathrm{cms}$. or $5 \mathrm{ft} .4 \mathrm{in}$. of lateral spread and a trunk diameter of $3.70 \mathrm{cms}$., approximately $11 / 2 \mathrm{in}$.

(b) That the average tree top and root system in this series weighed 1849.16 grs. and 207.97 grs. (dry weight) respectively.

(c) That the trunk diameter of coffee trees was more indicative of a heavy top and a strong, extensive, root system than either the height or lateral spread. The figures in table VIII show this clearly; the trees with a trunk diameter of $4 \mathrm{cms}$. or above are in general the trees having the heaviest and most extensive root systems. For comparing the root extensiveness of the six trees, refer to table VI. 
244 THE JOURNAL OF AGRICULTURE OF THE UNIVERSITY OF P. R.

TABLE VII

RATIO OF TOPS TO ROOTS OF EACH TREE BASED ON GREEN AND DRY WEIGHTS AND ITS RELATION TO MOISTURE AND FERTILIZER

\begin{tabular}{|c|c|c|c|c|c|}
\hline Tree number & $\begin{array}{l}\text { Fertilizer } \\
\text { applied }\end{array}$ & $\begin{array}{l}\text { Average per- } \\
\text { cent of soil } \\
\text { moisture for } \\
\text { all layers }\end{array}$ & Tops & Roots & $\begin{array}{l}\text { Ratio of tops } \\
\text { to roots }\end{array}$ \\
\hline \multirow{2}{*}{ 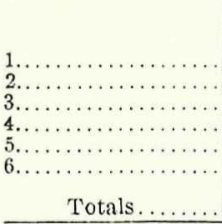 } & 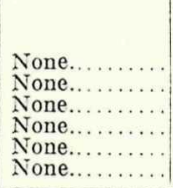 & $\begin{array}{l}22.93 \\
22.93 \\
22.93 \\
22.93 \\
22.93 \\
22.93\end{array}$ & $\begin{array}{l}\text { Grams } \\
\qquad \begin{array}{r}1,642.00 \\
2,038.00 \\
1,925.00 \\
1,471.00 \\
2,094.00 \\
1,925.00\end{array}\end{array}$ & $\begin{array}{l}\text { Grams } \\
\qquad \begin{array}{r}167.35 \\
300.36 \\
212.22 \\
12075 \\
196.79 \\
250.36\end{array}\end{array}$ & $\begin{array}{r}9.81 \\
6.78 \\
9.07 \\
12.18 \\
10.64 \\
7.68\end{array}$ \\
\hline & $\ldots \ldots \ldots \ldots \ldots$ & $\ldots \ldots \ldots \ldots$ & $11,095.00$ & $1,247.83$ & 8.88 \\
\hline \multicolumn{6}{|c|}{ GREEN WEIGHTS } \\
\hline 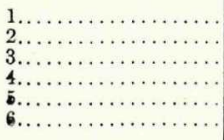 & 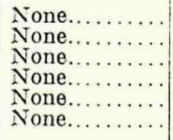 & $\begin{array}{l}22.93 \\
22.93 \\
22.93 \\
22.93 \\
22.93 \\
22.93\end{array}$ & $\begin{array}{l}2,500.00 \\
3,500.00 \\
3,100.00 \\
2,050.00 \\
3,400.00 \\
3,100.00\end{array}$ & $\begin{array}{l}338.09 \\
591.81 \\
404.08 \\
263.98 \\
396.95 \\
526.28\end{array}$ & $\begin{array}{l}7.39 \\
5.91 \\
7.67 \\
7.76 \\
8.57 \\
5.89\end{array}$ \\
\hline 'Totals. . & & & $17,650.00$ & $2,521.19$ & 7.00 \\
\hline
\end{tabular}




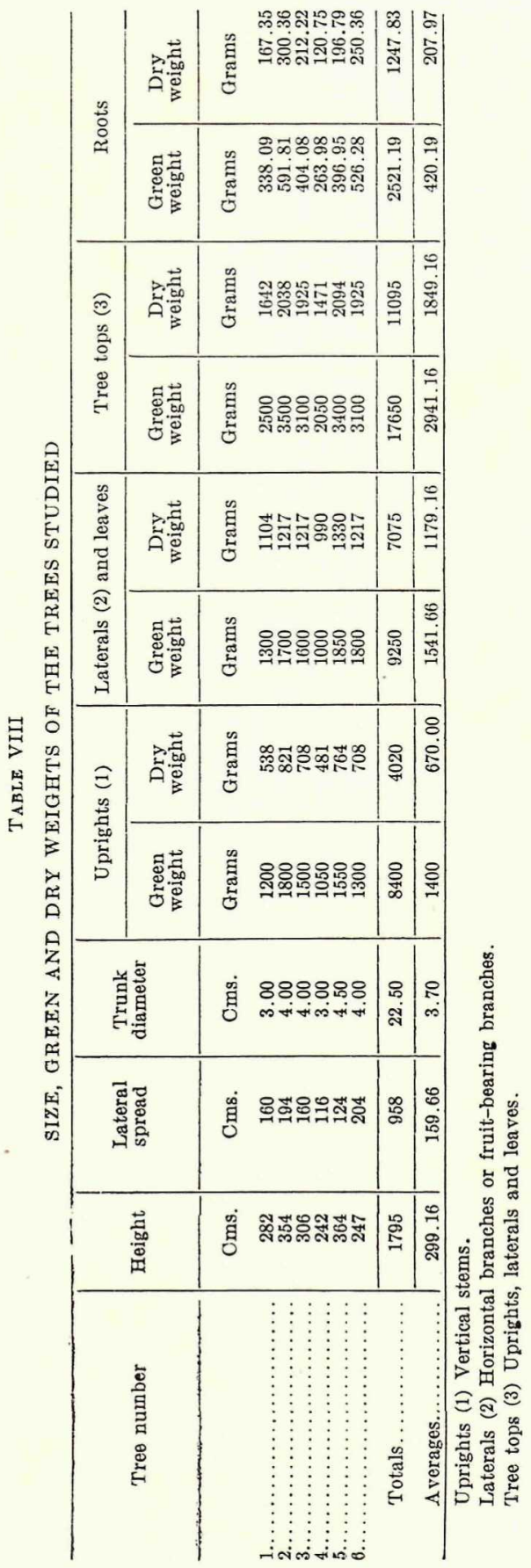


246 THE JOURNAL OF AGRICULTURE OF THE UNIVERSITY OF P. $R$.




Other information that can be obtained from table VIII is in relation to the water contents of uprights, lateral and leaves and roots. Based on the dry and green weights, there is approximately 50 percent of water in the uprights; 23 percent in the lateral branches and leaves, 39 percent in the whole tree tops and 50 percent in the roots. The figures definitely indicated the woodiness of the coffee tree.

\section{Discussion And Conclusions}

Recognizing the necessity of fundamental knowledge regarding the root system of coffee in Puerto Rico in order to be able to introduce better agronomic methods for growing this crop and to he able to offer definite explanations for failures attained, the present study was undertaken. A new method was used endeavoring to obtain abundant as well as accurate and reliable information. This method, consists in excavating one-cubic foot-blocks of soil in definite rolumes of soils corresponding to each of the trees under investigation. The green and dry weights of the roots found in each cubic foot of soil is obtained and by using an excavation map for each of the root systems, the weight as well as the rertical and horizontal distribution of the roois excavated for each tree is obtained. The method used, just mentioned is the outgrowth of methods previously used by Lee (2, (3), Nutman (6) and Gómez (1) for studying the root systems of sugar cane and coffee.

Lee (2), (3) trying to get a quantitative distribution of the roots of sugar cane at different soil levels designed and successfully executed an accurate, fast, practicable and relatively inexpensive method of studying root systems of plants which has been fully described. Using Lee's method, no roots are lost since these are carefully separated by screens and by hand as the soils is excavate? by 8 -inches layers at several depths. By weighing the roots excavated by layers, an accurate distribution of the roots of the plant studied at definite soil depths is obtained. However, no information is obtained as to the lateral extension of the roots. Lee's method has the further advantage that it is practicable under conditions naturally existing in commercial fields.

Gómez (1) followed Lee's method for studying the root system of sugar cane in the western part of Puerto Rico and obtained useful and practical information.

Weaver and his associates (9), (10) studied intensively the root systems of many different plants in the United States by working into the side of a trench with hand tools and following up the roots 
by breaking away the soil. Once the root system is exposed, it is drawn to scale in the field.

Although Weaver's method gives information as to the vertical penetration and lateral extension of the root systems, it must be recognized that a certain quantity of small roots must be lost necessarily in stiff soil since a soil of this nature breaks out in lumps of various sizes. The loss of these small roots will affect the results obtained because no accurate information can be obtained regarding the location of the real absorbing area of the root system. Besides, the information obtained in relation to the lateral extension of the roots is not representative because the roots do not probably extend to the same distances in all directions, taking as axis the trunk of the tree and its prolongation, the central root. In other words Weaver's method gives good information if the vertical penetration and lateral extension of the principal roots of the entire root system is desired, but since a certain quantity of the roots is lost, is impossible to get the real location of the absorbing surfaces at different soil levels.

Nutman (6) has used two methods for the study of the root system of coffee in Kenya. The first is very similar to that developed by Weaver and his associates (9), (10). The second method, which according to Nutman is possibly the most accurate method for studying the root system of plants consists, briefly, in washing away the soil in 1 foot cubes with fine jets of water at a definite selected section of the root system. The roots found at each cube are washed and the total length of the feeding roots measured.

The disadrantages of this method are obvious. In computing the total feeding area for the entire root system, it must be assumed that the average diameter and concentration of the root hairs is constant, a great percentage of the total roots is ignored since only a section of the entire root system is studied and the longitudinal measurement of the feeding roots must be necessarily a complicated and expensive procedure. Nutman developed this method believing that the longitudinal measurement of the feeding roots is the best indication of the absorbing area of the tree. But that the quantitative determination by weighing the roots is as good an indication of the absorbing capacity of the root system as longitudinal measurements, was first advanced and proved by Lee (2), (3) and later corroborated by Gómez (1) and the writers. Besides, although Nutmau insists on longitudinal measurements, the figure obtained with his method (6) indicate that the greatest concentration if feeding roots 
oceur in the top-most 12 inches of soil which definitely establishes the fact that the weight of roots at definite levels is an accurate means of determining the location of the absorbing area of the root system. Th:s is to be expected since the concentration of large numbers of feeding roots although of small size and weight will affect the total weight of the roots found at a definite soil depth.

Nutman's (4), (5), (6) intensive works on the root system of: coffee in various types of soil in Kenya, have undoubtly contributed to explain and solve important problems related with the coffee industry of that country.

Nutman (5) also studied the effects of various soil conditions in modifying the root-growth of coffee trees and found that in general, hard-pan has little effect on root development; lava, mud-stone gravel strata and high water-iable cause penetration to be inhibited in greater or less degree and that the acid limit of satisfactory growth is at a $\mathrm{pH}$ of 5.8 to 6.00 .

According to the results obtained in this study 94 percent of coffee roots of 7 -year-old trees in Coloso Clay are found in the topmost 12 inches of soil. 'These results generally agree with Nutman's results in Kenya (6) by which he found the greatest concentration of roots in the top-most 12 inches of soil, with Lee's (2) results in which he found that sugar cane either hilled-up or in furrows, more than 85 percent of the roots were found in the top-most 24 inches of soil and with Gómez (1) results in Puerto Rico in which 51.39 percent of the total amount of roots excavated at a depth of from 0 to 48 inches, is found in the hilled-up and top-most 0-8 inch soil depth.

However, it is believed by the writers that the concentration of 94 percent of the total amount of roois excavated is a little abnormal and that must be due to an abnormal soil conclition, in this case, the imperfect drainage typical of the Coloso Clay soil. From measurements taken on individual 2-year old trees in the coffee experimental fields planted at the Puerto Rico Experiment Station of the United States Department of Agriculture at Mayagüez which indicate the height, lateral spread and trunk diameter that may be attained by trees under proper soil and eultivation, and from observations made on individual trees at commercial fields, it is found when comparing the growth of trees used for this study with trees of less age, that the 6 trees studied had not developed properly.

The Coloso Clay Soil being regarded as a productive soil in Puerio Rico is not responsible for the growth attained by the trees in 7 years, but the improper drainage due to special environmental con- 
ditions prevailing in the locality where the excavations were performed. It is expected that with better drainage conditions the growth attained by the six trees would had been greater and the penetration and lateral extension of the root system would had been greater also at the various soil depths studied.

Although Coloso Clay is not the most common type of soil found in the coffee region of Puerto Rico it is present at flat, level places, near streams in farms where the Catalina Clay is abundant. Therefore, it is recomemnded to provide the coffee plantations growing in localities of conditions similar to those prevailing at the place where these studies were conducted, with proper drainage so that the growth of the trees may be normal and the production of the field, greater.

The relatively high percent of organic matter of Coloso Clay accounts to some extent for the greater concentration of roots at the top-most 12 inches of soil although the effect of better aeration of surface layers is also responsible for a greater quantity of roots to be present in the first layer excavated. Nutman (5) found that manurial aplications always resulted in an increased feeder-growth in the neighborhood of the manure.

Apparently, the texture of the soil and the concentration of the principal plant foods do not affect the growth of roots. This applies especially to the results obtained by this study because with the exception of a few figures of the physical and chemical analyses of the 4 soil depths studied, the texture and the concentration of $\mathrm{nu}$ rients was quite uniform for the 4 layers in which roots were excarated.

Contrary to the common believe that an exhuberant vegetative condition of tree tops must be correlated with a heavy and extensive root system, the results obtained in this study indicate that the conditions of growth of tree tops cannot be considered in figuring the conditions of growth of the root system because a heavy top is not dependent on a strong and extensive root system, judging from the figures shown in tables V, VI and VIII. The results obtained are in accord with those obtained by Lee (2), (3) and Gómez (1) in their stuides of the root systems of sugar cane in Hawaii, the Philippine Islands and Puerto Rico.

According to the figures shown by table VII there is no fixed ratio of tops to roots in coffee no matter whether dry or green weights of tops and roots are used for determining the ratio. This accords with Weaver's (9), (10) results with siudies of the root systems of plants in the United States. It may be stated conclusively that the ratio of tops to roots of young coffee trees was approximately $8: 1$. 
In selecting trees with a vigorous and abundant vegetative condition at the tops and strong, extensive root systems, the diameter of the trunk is a better indication of the possession of these desirable characteristics than either the lateral spread or the height. This was shown definitely by the figures in tables VI and VIII already explained. In the six trees studied, those with a trunk diameter of 4 cms. or above were the trees with the heavier tops and heavier and more extensive root systems.

The new method of studying root systems of crop plants, developed by the writers and used for studying the root system of coffee, $C$. arabica $\mathrm{L}$. in Puerto Rico, besides making it possible to obtain the information discussed already, enables us to propose a description for the root system of coffee based strictly on the results obtained. Such root system may be described to have the form of an inverted cone with a wide base; the spread of the roots in the top-most 12 inches of soil, and a rather small height, the vertical penetration. There is really no pivot or main root in the coffee root system. The broad, central root noticed in text figure No. 2, is part of the stem, buried as a result of a tendency of our farmers to plant the coffee seedling's too deep into the planting holes. At a very short distance from the collar of the stems (the collar is regarded as that point in between the stem and the root system) a number of roots are found spreading out laterally and vertically which have a greater diameter than any other roots in the system. These main or primary roots give rise to secondary and tertiary roots, each of smaller diameter, and largely on the tertiary roots the root hairs are originated. According to the results obtained and the observations made in the field, the tertiary roots with root hairs are present in great quantities in the top-most 12 inches of soil and they originate at any point or distance from the center of the root system. The tertiary roots with the root hairs may originate at any part of either the main or secondary roots. It must be explained that the terminology of main, secondary and tertiary is based on the diameter of the roots and not on a systematic branching, in other words, tertiaries with root hairs have been observed to occur even on the buried stem adjoining the root system.

From the description of the root system just proposed it may be concluded that the absorbing area of the root system of coffee is not confined to definite places on the soil, but is evenly distributed in all places penetrated by the main and secondary roots. 


\section{Application of the Results Obtained}

Athough the results obtained thus far need further confirnation, with the information gathered, it is possible to make some recommendations for the improvement of agricultural operations followed in the coffee plantations as follows:

(a) The greatest quantity of roots, 94 percent of the total roots excavated for the six trees, is found in the topmost 12 inches of soil.

(b) In the top-most 12 inches of soil, the roots of some of the trees extended laterally more than four feet.

(c) The maximum vertical penetration of the roots of inost irees is three feet.

(d) The high content of the organic matter of the excavated at the top-most 12 inches and the better aeration of surface layers are apparently responsible for the greater quantities of roots found in the top-most 12 inches of soil.

In view of these facts, the young coffee tree is a surface feeder and shade trees or crop plants such as oranges and bananas should never be interplanted with coffee because of similar root-habits. In case, bananas are used to provide shade to the young coffee seedlings, the banana plants should be eliminated as soon as the permanent shade trees provide the coffee with the desired shade. Also, the excessive number of shade trees per cuerda, usually noticed in the plantations should be eliminated in order to reduce the competition for plant food to a minimum.

Coffee seedlings should always be planted at a minimum distance of $8 \mathrm{ft}$. $\times 8 \mathrm{ft}$. This is shown clearly in the first layers of the excavation maps (text figures 3 to 8 ) of most trees. The roots in the top-most 12 inches extended laterally $4 \mathrm{ft}$. or more showing that young trees in a relatively small number of years need and individual area of 64 sq. ft. for the development of the roots. When it is supposed that older trees will develop stronger and more extensive root systems it is realized that the minimum planting distance must be at $8 \times 8 \mathrm{ft}$. Therefore, a cuerda of coffee should not have more than 625 coffee trees in order to provide an adequate land surface from which to withdraw an ample supply of plant foods.

The surface-feeding habit of coffee trees specially while young requires deep soils for a reasonable amount of growth and productivity. Many failures to grow coffee on shallow soils have been recorded. 
Tree no. 2

First layer: 0"12:"

\begin{tabular}{|c|c|c|c|c|c|c|c|}
\hline & & & & & & & \\
\hline 0 & 0 & 으 & 199 & 1051 & 0.0907 & 027 & 0.0 \\
\hline & B. 10 & B.11 & & & B. 14 & 3.15 & B. 1 \\
\hline 0614 & 5550 & 0.1762 & 080 & 164 & 10 & & \\
\hline 17 & B. 18 & $B$ & 320 & B.21 & B-22 & B.23 & D \\
\hline  & 19 & 2.8 & 50 & 534 & 1.3930 & $\mid 0.0^{\circ}$ & \\
\hline 25 & B.26 & B. 27 & B. 28 & D. & B. 30 & B.31 & B.3 \\
\hline 074 & 6196 & 3.2926 & 50.3452 & 581010 & 2.6846 & 486 & \\
\hline 33 & 34 & B. 35 & B. 36 & B. 37 & B.38 & B.39 & B.4C \\
\hline 0 & 3112 & 0.9170 & 854 & 18.4422 & 1.1974 & 3558 & 30 \\
\hline 41 & 42 & B-43 & 44 & $0^{\circ} .45$ & B.46 & B. 47 & B-4 \\
\hline 은 & 6 & 0.2964 & 498 & 4.4640 & 1.8186 & 0.2798 & \\
\hline 49 & B. 50 & B. 51 & B.52 & B-53 & B. 54 & B- 55 & B. 5 \\
\hline 0 & 0 & 0 & 0.1200 & 690 & 0.5060 & & 0.0342 \\
\hline & B.58 & B-59 & B. 60 & $B-6$ & B62 & B. 63 & B.64 \\
\hline & & & & & & & \\
\hline
\end{tabular}

Third layer: $24^{\prime \prime}-36^{\prime \prime}$

\begin{tabular}{|c|c|c|c|c|c|c|c|}
\hline $\mathrm{B} \cdot 1$ & $\mathrm{~B} \cdot 2$ & $\mathrm{~B} \cdot 3$ & $\mathrm{~B} \cdot 4$ & $\mathrm{~B} \cdot 5$ & $\mathrm{~B} \cdot 6$ & $\mathrm{~B} \cdot 7$ & $\mathrm{~B} \cdot 8$ \\
0 & 0 & 0 & 0 & 0 & 0 & 0 & 0 \\
\hline $\mathrm{B} \cdot 9$ & $\mathrm{~B} 10$ & $\mathrm{~B} \cdot 11$ & $\mathrm{~B} \cdot 12$ & $\mathrm{~B} \cdot 13$ & $\mathrm{~B} \cdot 14$ & $\mathrm{~B} \cdot 15$ & $\mathrm{~B} \cdot 16$ \\
0 & 0 & 0 & 0 & 0 & 0 & 0 & 0 \\
\hline $\mathrm{B} \cdot 17$ & $\mathrm{~B} \cdot 18$ & $\mathrm{~B} \cdot 19$ & $\mathrm{~B} \cdot 20$ & $\mathrm{~B} \cdot 21$ & $\mathrm{~B} \cdot 22$ & $\mathrm{~B} \cdot 23$ & $\mathrm{~B} \cdot 24$ \\
0 & 0 & 0 & 0 & 0 & 0 & 0 & 0 \\
\hline $\mathrm{B} \cdot 25$ & $\mathrm{~B} \cdot 26$ & $\mathrm{~B} \cdot 27$ & $\mathrm{~B} \cdot 28$ & $\mathrm{~B} \cdot 29$ & $\mathrm{~B} \cdot 30$ & $\mathrm{~B} \cdot 31$ & $\mathrm{~B} \cdot 32$ \\
0 & 0 & 0 & 0 & 0.054 & 0.0208 & 0 & 0 \\
\hline $\mathrm{B} \cdot 33$ & $\mathrm{~B} \cdot 34$ & $\mathrm{~B} \cdot 35$ & $\mathrm{~B} \cdot 36$ & $\mathrm{~B} \cdot 37$ & $\mathrm{~B} \cdot 38$ & $\mathrm{~B} \cdot 39$ & $\mathrm{~B} \cdot 40$ \\
0 & 0 & 0 & 0.0454 & 0 & 0 & 0 & 0 \\
\hline $\mathrm{B} \cdot 41$ & $\mathrm{~B} \cdot 42$ & $\mathrm{~B} \cdot 43$ & $\mathrm{~B} \cdot 44$ & $\mathrm{~B} \cdot 45$ & $\mathrm{~B} \cdot 46$ & $\mathrm{~B} \cdot 47$ & $\mathrm{~B} \cdot 48$ \\
0 & 0 & 0 & 0 & 0 & 0 & 0 & 0 \\
\hline $\mathrm{B} \cdot 49$ & $\mathrm{~B} \cdot 50$ & $\mathrm{~B} \cdot 51$ & $\mathrm{~B} \cdot 52$ & $\mathrm{~B} \cdot 53$ & $\mathrm{~B} \cdot 54$ & $\mathrm{~B} \cdot 55$ & $\mathrm{~B} \cdot 56$ \\
0 & 0 & 0 & 0 & 0 & 0 & 0 & 0 \\
\hline $\mathrm{B} \cdot 57$ & $\mathrm{~B} \cdot 58$ & $\mathrm{~B} \cdot 59$ & $\mathrm{~B} \cdot 60$ & $\mathrm{~B} \cdot 61$ & $\mathrm{~B} \cdot 62$ & $\mathrm{~B} \cdot 63$ & $\mathrm{~B} \cdot 64$ \\
0 & 0 & 0 & 0 & 0 & 0 & 0 & 0 \\
\hline
\end{tabular}

Second layer: 12:24"

\begin{tabular}{|c|c|c|c|c|c|c|c|}
\hline 0 & $\begin{array}{r}\text { B2 } \\
0\end{array}$ & $\begin{array}{l}3.3 \\
0\end{array}$ & 0 & $\begin{array}{l}5 \\
0\end{array}$ & $\begin{array}{l}6 \\
0\end{array}$ & 3.7 & 8 \\
\hline 9 & B 10 & B.11 & & 13 & 314 & 315 & 8.16 \\
\hline 0 & 0 & & & & & & \\
\hline & & & & & & $0<$ & $D \cdot 6$ \\
\hline & 0618 & 18 & tore & 0.2472 & & & \\
\hline 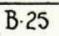 & B.26 & B.27 & B. & $8-29$ & B-30 & D.3 & $B \cdot 3$ \\
\hline & 0 & 668 & 0.7162 & {$[0.4862 \mid$} & 0 & 0 & \\
\hline 33 & 34 & $B \cdot 35$ & 36 & B.37 & B.38 & 39 & B.4 \\
\hline 0 & 0 & 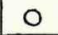 & 0.6818 & 0.1612 & 0.0416 & 2.0197 & 0 \\
\hline & B. 42 & B-43 & 5.44 & B.45 & B-46 & B-47 & \\
\hline & & & 08 & .1680 & 0.4492 & 0.0 & \\
\hline & $B$ & B. 51 & B.52 & B-53 & B.54 & B.55 & B. 5 \\
\hline & & & 054 & 0 & 0.0384 & 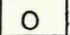 & \\
\hline & B.58 & B. 59 & B.60 & B.61 & B.62 & $B \cdot 63$ & $B \cdot E^{\prime}$ \\
\hline & & & & & & & \\
\hline
\end{tabular}

Fourth layer: $36^{\circ}-48^{\circ}$

\begin{tabular}{|c|c|c|c|c|c|c|c|}
\hline 0 & $\begin{array}{r}B \cdot 2 \\
0\end{array}$ & $\begin{array}{r}\text { B.3 } \\
0\end{array}$ & $\begin{array}{c}\text { B.4 } \\
0\end{array}$ & $\begin{array}{c}\text { B.5 } \\
0\end{array}$ & $\begin{array}{c}\text { B.6 } \\
0\end{array}$ & $\begin{array}{r}\text { B-7 } \\
0\end{array}$ & $\begin{array}{r}B \cdot 8 \\
0\end{array}$ \\
\hline 9 & $B 10$ & B.11 & B. 12 & B. 13 & B. 14 & B 15 & B.16 \\
\hline 0 & 0 & & 0 & 0 & 0 & 0 & 0 \\
\hline 17 & B.18 & B 19 & B20 & B. 21 & B.22 & B.23 & B. 24 \\
\hline & 0 & & 0 & 0 & 0 & 0 & \\
\hline 25 & B.26 & $\mathrm{B} 27$ & B.28 & B.29 & B.30 & B. 31 & B. 32 \\
\hline 0 & 0 & & 0 & 0 & 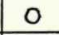 & 0 & 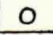 \\
\hline 33 & B. 34 & B. 35 & B.36 & $B \cdot 37$ & B.38 & B.39 & B. 40 \\
\hline 0 & 0 & & 0 & 0 & 0 & 0 & \\
\hline 44 & B. 42 & B. 43 & B. 44 & B. 45 & B.46 & B.47 & $B \cdot 48$ \\
\hline 0 & 0 & & 0 & 0 & 0 & 0 & 0 \\
\hline 49 & B. 50 & B.51 & B.52 & B. 53 & B.54 & B. 55 & B. 56 \\
\hline 0 & 0 & 0 & 0 & 0 & 0 & 0 & 0 \\
\hline 57 & B.58 & B.59 & B.60 & $\mathrm{B}-61$ & B.62 & B.63 & B.64 \\
\hline 0 & 0 & & & 0 & 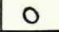 & 0 & 0 \\
\hline
\end{tabular}

B-12= block number; $0.0274=$ dry weight in grams of roots in one cubic foot of soil; - - location of tree trunk; $\mathrm{O}=$ blocks without roots.

Diagram indicating dry weight of roots per cubic foot of soll excavated in each layer of tree 1 . 
Tree no.2

First layer: $0^{\circ} 12^{*}$

\begin{tabular}{|c|c|c|c|c|c|c|c|}
\hline 65 & B. 66 & B. 67 & B. 68 & B.69 & B.70 & B. 71 & B-T2 \\
\hline 0 . & 0 & 1.2058 & 0.7715 & 0.0398 & 0.0782 & 0.0918 & 0 \\
\hline 3.73 & B. 74 & B. 75 & B. 76 & B. 77 & B.78 & B. 79 & B. 80 \\
\hline 554 & 0.0766 & 0.0704 & 0.3506 & 0.4992 & Q. 1732 & 0.0050 & 0.017 \\
\hline 81 & B. 82 & B. 83 & B. 84 & B.85 & B. 86 & B.8? & B. 8 \\
\hline 0 & 0.0920 & 0.4902 & 5.5076 & 2.8896 & 0.8294 & 0.089 & 0 \\
\hline 89 & B. 90 & B.91 & B. 92 & B. 93 & B. 94 & B. 95 & B.96 \\
\hline 0034 & 0.3116 & 3.7120 & 17.5400 & 2.8812 & 1.9848 & 0.3132 & Q \\
\hline 3.97 & B.98 & B.99 & B-100 & B. 101 & B-102 & B. 10. & B. 10 \\
\hline 은 & 0 & 1.4472 & $192.5^{\circ}$ & 28.67 & 2.3648 & 0 & 0 \\
\hline 105 & B.106 & B.107 & B. 108 & B.109 & B 110 & B. 111 & B. 11 \\
\hline 0 & 0 & 2.0811 & 8.1050 & 5.3400 & 2.2678 & 0.1986 & 0 \\
\hline 113 & B.114 & B'115 & B.116 & B. 117 & B. 118 & B. 119 & B 12 \\
\hline 0 & 0 & 0 & 2.5502 & 1.7394 & 0.1434 & 0 & 0 \\
\hline 121 & \begin{tabular}{|l|l|} 
B-122. \\
122
\end{tabular} & B. 123 & B 124 & B. 125 & B. 126 & B. 127 & B. 128 \\
\hline & & o & 0.46 & 3518 & 0 & & \\
\hline
\end{tabular}

Third layer: $24^{*}-36^{*}$

\begin{tabular}{|c|c|c|c|c|c|c|c|}
\hline 65 & B.66 & B. 67 & B.68 & B.69 & B.70 & B 71 & 3.72 \\
\hline 0 & 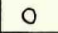 & 0 & 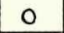 & 0 & 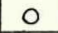 & 0 & 0 \\
\hline 73 & B.74 & B.75 & B. 76 & B. $\cdot 77$ & B.78 & B.79 & B. 80 \\
\hline 0 & 0 & 0 & 0 & 0 & 0 & 0 & 0 \\
\hline 81 & B.82 & B.83 & B-84 & B.85 & B.86 & B. 87 & B. 88 \\
\hline 0 & 0 & 0.1008 & 0.0400 & 0 & 0 & 0 & 0 \\
\hline 8.89 & $B .90$ & B.91. & B.92 & B. 93 & B.94. & B. 95 & B.96 \\
\hline 0 & 0 & 0 & 0 & 0 & 0 & 0 & 0 \\
\hline 3.97 & B.98 & B.99 & B. 100 & B. 101 & B.102 & B. 103 & B. 104 \\
\hline 0 & 0 & 0 & 0.6730 & 0.1980 & 0 & 0 & 0 \\
\hline 8.105 & B. 106 & B-107 & B. 108 & B. 109 & B. 110 & B.111 & B.112 \\
\hline 0 & 0 & 0 & 0 & 0.0254 & 0 & 0 & 0 \\
\hline B. 113 & B-114 & B. 115 & B. 116 & B. 117 & B118 & B.119 & B. 120 \\
\hline 으 & 은 & 0 & 0 & 0 & 0 & 0 & 은 \\
\hline 8.121 & B 122 & B-123 & B-124 & 8125 & B.126 & B 127 & B. 128 \\
\hline 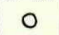 & . & 0 & 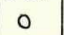 & 0 & . & 0 & 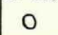 \\
\hline
\end{tabular}

Secondlayer: $12=24 "$

\begin{tabular}{|c|c|c|c|c|c|c|c|}
\hline 5 & 66 & B.6? & B. 68 & B. 69 & B-70 & B.71 & B.? \\
\hline 0 & 0 & 0 & 0 & 0 &  & 0 & 0 \\
\hline 8.73 & B.74 & B.75 & B.76 & B.77 & B. 78 & B.79 & B.8C \\
\hline O & 0 & 0 & 0.1092 & 0.1034 & 0 & 0 & \\
\hline 81 & B. 82 & B 83 & 34 & B.85 & B. 86 & B. 87 & B. 88 \\
\hline 0 & 0 & 0 & 0.6890 & 00.3878 & 0.083 & 0 & 0 \\
\hline 8.89 & B. 90 & B.91 & B' 92 & B.93 & B.94 & B-95 & B. 96 \\
\hline 0 & 0 & 0 & 0.1385 & 1.1808 & 0.1122 & 0 & 0 \\
\hline B.97 & B-98 & B.99 & B. 100 & B.101 & B. 102 & B.103 & B. 10 \\
\hline 0 & 0 & 0.077 & 3.3 & .1478 & 0.1680 & 0 & 0 \\
\hline 3.105 & B. 106 & B 107 & B. 108 & B.109 & B. 110 & B. 111 & B.11 \\
\hline 0 & 0 & 0.123 & 1.1730 & 0.806 & 0.3991 & 0.41 & \\
\hline $3-113$ & B. 114 & B. 115 & B 116 & B-117 & B. 118 & B-119 & B.12 \\
\hline 0 & 0 & 0 & 0.2008 & 0.0456 & 0 & 0 & 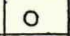 \\
\hline 121 & B.122 & B.123 & B 124 & B. 125 & B. 126 & B.127 & B. 128 \\
\hline C & 0 & & 079 & & & & 0 \\
\hline
\end{tabular}

Fourth layer: $36^{\prime \prime}-48^{n}$

\begin{tabular}{|c|c|c|c|c|c|c|c|}
\hline 65 & 3.66 & B 67 & B 68 & $B 69$ & B.70 & B.71 & B. 7 \\
\hline 0 & 0 & 0 & 0 & 0 & 0 & 0 & 0 \\
\hline 8.73 & B.74 & B 75 & B 76 & B. 77 & B.78 & B.79 & B. 80 \\
\hline 0 & 0 & 0 & 0 & 0 & 0 & 0 & 0 \\
\hline 881 & B 82 & B. 83 & B.84 & B.85 & B. 86 & B. 87 & B. 88 \\
\hline 0 & 0 & 0 & 0 & 0 & 0 & 0 & 0 \\
\hline 389 & B90 & B 91 & B. 92 & B.93 & B. 94 & B. 95 & B. 96 \\
\hline 0 & 0 & 0 & 0 & 0 & 0 & 0 & 0 \\
\hline B-97 & B 48 & B. 99 & B 100 & B.101 & B.102 & $B .103$ & B. 104 \\
\hline 0 & 0 & 0 & 0 & 0 & 0 & 0 & 0 \\
\hline 3.105 & B. 106 & B. 107 & B-108 & B. 109 & B.110 & B-111 & B.112 \\
\hline 0 & 0 & 0 & 0 & 0 & 0 & 0 & 0 \\
\hline B. 113 & B.114 & B 115 & B. 116 & B. 117 & B. 118 & B. 119 & B 120 \\
\hline 0 & 0 & 0 & 0 & 0 & 0 & 0 & 0 \\
\hline 3121 & B 122 & B 123 & B 124 & B. 125 & B. 126 & B. 127 & B. 128 \\
\hline 0 & 0 & 0 & 0 & 0 & 0 & 0 & 0 \\
\hline
\end{tabular}

B-67= block. number; $1.2058=$ dry weight in qrams of roots insone cubic foot of soll;

- localion of tree trunk; $0=$ blocks without roots.

Diagram indicating dry weight of roots per cubic foot of soil excavated in each layer of tree 2. 
Tree no.3

First layer: $0: 12^{\circ}$

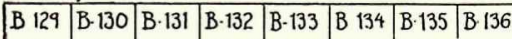
\begin{tabular}{lllllllllllll}
\hline & 0 & $O$ & 0.5932 & 0.5557 & 0.0404 & 0.0518 & 0.4178 \\
\hline
\end{tabular} \begin{tabular}{|l|l|l|l|l|l|l|l|l|l|l|}
\hline B. 137 & B 138 & B 139 & B. 140 & B 141 & B. 142 & B 143 & B. 144 \\
\hline
\end{tabular} \begin{tabular}{lllllllllll}
\hline 0.0027 & $O$ & 0.0290 & 0.2948 & 0.1880 & 0.2717 & 0.2120 & 0.0092 \\
\hline
\end{tabular} \begin{tabular}{|l|l|l|l|l|l|l|l|l|}
\hline B.145 & B-116 & B-147 & B-148 & B-149 & B 150 & B. 151 & B. 152 \\
\hline
\end{tabular} \begin{tabular}{llllllllllll}
0.0268 & 0.0077 & $O$ & 0.3308 & 1.5154 & 2.9248 & 0.1297 & 0.1114 \\
\hline
\end{tabular} \begin{tabular}{|l|l|l|l|l|l|l|l|l|l|l|l|}
\hline B. 153 & B- 154 & B- 155 & B- 156 & B. 157 & B- 158 & B. 159 & B. 160 \\
\hline
\end{tabular} \begin{tabular}{lllllllllll}
\hline 0.0710 & 0.8109 & 1.7728 & 1.2538 & 8.4284 & 7.4792 & 0.8512 & 0.0766 \\
\hline
\end{tabular} \begin{tabular}{|l|l|l|l|l|l|l|l|l|l|l|}
\hline B. 161 & B. 162 & B 163 & B-164 & B. 165 & B-166 & B-167 & B- 168 \\
\hline
\end{tabular} \begin{tabular}{llllllllll}
\hline & 0 & 2.1461 & 106.52 & 4.8424 & 27.2988 & $\bigcirc$ & 0.0898 \\
\hline
\end{tabular} \begin{tabular}{|l|l|l|l|l|l|l|l|}
\hline B. 169 & B. 170 & B. 171 & B. 172 & B. 173 & B. 174 & B. 175 & B. 176 \\
\hline
\end{tabular} $\begin{array}{llllllllll}0.3542 & 0.1826 & 2.4066 & 9.1652 & 10.8420 & 3.4560 & 0.4246 & O\end{array}$ \begin{tabular}{l|l|l|l|l|l|l|l|l|l|}
\hline B. 177 & B. 178 & B. 179 & B. 180 & B. 181 & B. 182 & B. 183 & B. 184 \\
\hline
\end{tabular} \begin{tabular}{lllllllllllll}
\hline & 0 & 0.4764 & 0.6348 & 1.4670 & 0.4746 & 0.2610 & 0
\end{tabular}

\begin{tabular}{|c|c|c|c|c|c|c|c|}
\hline B.185 & B.186 & B. 187 & B. 188 & B. 189 & B. 190 & B. 191 & B. 192 \\
\hline
\end{tabular}

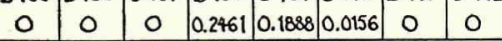

Third layer: $24^{\circ}-36^{\circ}$

\begin{tabular}{|c|c|c|c|c|c|c|c|}
\hline 129 & $B \cdot 130$ & B.131 & B-132 & B-133 & B.137 & B.135 & B. 136 \\
\hline 0 & & & & & & & \\
\hline 137 & B 138 & B. 139 & B. 140 & B.141 & B. 142 & 3.143 & B. 144 \\
\hline 0 & 0 & 0 & 0 & 0 & 0 & 0 & 0 \\
\hline 3.145 & B.146 & B.147 & B-148 & B.149 & B. 150 & B. 151 & B.152 \\
\hline 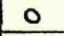 & 0 & 0 & 0 & 0 & 0 & 0 & 으 \\
\hline 3.153 & B-154 & B. 155 & B. 156 & B. 15? & B. 158 & B. 159 & B. 160 \\
\hline 0 & 0 & 0 & 0 & 0 & 으 & 0 & 은 \\
\hline $\begin{array}{c}B \cdot 161 \\
0\end{array}$ & $\begin{array}{c}\text { B-162 } \\
0\end{array}$ & $\begin{array}{c}B 163 \\
0\end{array}$ & $\begin{array}{l}\text { B-169 } \\
0.0985\end{array}$ & $\begin{array}{l}\text { B. } 165 \\
0.0320\end{array}$ & \begin{tabular}{|c|} 
B.166 \\
0
\end{tabular} & $\begin{array}{c}\text { B.167 } \\
\text { O }\end{array}$ & $\begin{array}{c}\text { B } 168 \\
0\end{array}$ \\
\hline B.169 & B-170 & B-171 & B.172 & B- 173 & B-174 & B.175 & B. 176 \\
\hline 0 & 0 & 0.0474 & 0.0858 & 0 & 0 & 0 & 0 \\
\hline B.177 & B 178 & B.179 & B. 180 & B.181 & B-182 & B. 183 & B. 184 \\
\hline 0 & 0 & 0 & 0 & 0 & 0 & 0 & 0 \\
\hline 85 & B. 186 & B.187 & B-188 & B-189 & B.190 & B.191 & B.192 \\
\hline & 0 & 0 & o & o & 0 & $\circ$ & .0 \\
\hline
\end{tabular}

Second layer : $12=24^{*}$

\begin{tabular}{|c|c|c|c|c|c|c|c|}
\hline $\begin{array}{c}\text { B. } 129 \\
0\end{array}$ & \begin{tabular}{|c|} 
B. 130 \\
0
\end{tabular} & $\begin{array}{c}131 \\
0\end{array}$ & \begin{tabular}{|c|}
$B 132$ \\
0
\end{tabular} & & $\begin{array}{c}\text { B.134 } \\
0\end{array}$ & & $\begin{array}{c}\text { B.136 } \\
0\end{array}$ \\
\hline 137 & B. 138 & B.139 & B.140 & B.191 & B.142 & B. 143 & B. 14 \\
\hline 0 & 0 & 0 & 0.1488 & 0.6322 & 0 & & \\
\hline 145 & B.146 & B.147 & B. 148 & B.149 & B. 150 & B. 151 & $8 \cdot 15$ \\
\hline 0 & 0 & 0 & 0 & 0.2440 & 0.1214 & 0 & \\
\hline B-153 & B. 154 & B.155 & B.156 & B. 157 & B.158 & B 159 & B. 16 \\
\hline 으 & 0 & 0.2544 & 0.2934 & 0.2792 & 0 & 0 & \\
\hline B. 161 & B.162 & B. 163 & B 164 & B. 165 & B. 166 & B.167 & $B \cdot 16$ \\
\hline 0 & 0.1138 & 0.8323 & $1.811^{4}$ & 2.2794 & 0.8820 & 0 & \\
\hline B.169 & B-170 & B. 171 & B 172 & B. 173 & B. 1174 & B. 175 & B.11 \\
\hline 은 & 0.2770 & 0.1824 & 14356 & 0.4230 & 0.5888 & 30.0706 & 0 \\
\hline B-171 & B. 178 & B-179 & B. 180 & B. 181 & B. 182 & B-18 & 8 \\
\hline 0 & 0 & 0 & 0.4804 & 0 & 0 & 0 & \\
\hline B.185 & B. 186 & B. 187 & B. 188 & B. 189 & B. 1190 & B-19 & $B-1$ \\
\hline 0 & 0 & 0 & 0 & 0 & 0 & & \\
\hline
\end{tabular}

Fourth layer: $36^{*}: 48^{\circ}$

\begin{tabular}{|c|c|c|c|c|c|c|c|}
\hline $\begin{array}{c}3129 \\
0\end{array}$ & \begin{tabular}{|c|} 
B.130 \\
0
\end{tabular} & \begin{tabular}{|c|} 
B. 131 \\
0
\end{tabular} & \begin{tabular}{c|c|}
$B 132$ \\
0
\end{tabular} & \begin{tabular}{|c|} 
B. 133 \\
0
\end{tabular} & \begin{tabular}{|c|}
$B \cdot 134$ \\
0
\end{tabular} & $\begin{array}{c}\text { B.1135 } \\
0\end{array}$ & $\begin{array}{c}\text { B.196 } \\
0\end{array}$ \\
\hline B-137 & B.138 & B.139 & B.140 & B.141 & B.142 & B.143 & B.144 \\
\hline 0 & 0 & 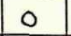 & U & 0 & 0 & 0 & 0 \\
\hline 3145 & B-146 & B:147 & B-148 & B.149 & B. 150 & B.151 & B.152 \\
\hline 0 & 0 & 0 & 0 & 0 & 0 & 0 & \\
\hline B 153 & B-154 & B. 155 & B-156 & B.157 & B-158 & B. 159 & $B \cdot 160$ \\
\hline 0 & 0 & 0 & 0 & 0 & 0 & 0 & 0 \\
\hline B 161 & B-162 & $B 163$ & B. 164 & B.165 & B. 166 & B.167 & B. 168 \\
\hline 0 & 은 & 0 & 0 & 0.1208 & 0.3075 & 0 & 0 \\
\hline B-169 & B970 & B. 121 & B-1172 & B. 173 & B. 174 & B. 175 & B.176 \\
\hline 0.2238 & 0 & 0 & 0 & 0 & 0 & 0 & 0 \\
\hline \begin{tabular}{|l|l|} 
B 117 \\
\end{tabular} & B-118 & B-179 & B. 180 & B. 181 & B. 182 & B. 183 & B. 184 \\
\hline 0 & 0 & 0 & 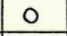 & 0 & 0 & 으 & 0 \\
\hline 185 & B- 186 & B-187 & B. 188 & B.189 & B.190 & B-191 & B.192 \\
\hline 0 & 0 & 0 & & 0 & 0 & 0 & ? \\
\hline
\end{tabular}

B-132-block number; 0.5932 - dry weight in grams of roots in one cubic fool of soil;

- $=$ location of tree trunk; $O=$ blocks without roots

Diagram indicating dry weight of roots per cubic foot of soil excavated in each layer of tree 3 .

Text fiqureno.5 
Tree no.4

Firstlayer : $0^{\circ}-12^{\prime \prime}$

\begin{tabular}{|c|c|c|c|c|c|c|c|}
\hline $\begin{array}{c}3.193 \\
0\end{array}$ & $\begin{array}{c}B-194 \\
0\end{array}$ & $\begin{array}{c}\text { B. } 195 \\
0\end{array}$ & $\begin{array}{l}B \\
B \\
0.9023\end{array}$ & B.197 & B. 198 & B.199 & $\begin{array}{c}820 \\
0\end{array}$ \\
\hline 201 & B.202 & B 203 & B 204 & B-205 & B.206 & B 207 & B. 208 \\
\hline 194 & 0.0192 & 0 & & 0 & & 0 & \\
\hline 209 & B. 210 & $2 \pi 1$ & $B \cdot 212$ & B-213 & B. 2 & $B 21$ & $B 21$ \\
\hline 0 & 0 & 1.0567 & 0.0442 & 0.0400 & 0 & 0 & \\
\hline 217 & $3-218$ & B. 219 & B-220 & B. 221 & B. 222 & B.223 & B.22 \\
\hline 0 & $0.38 \%$ & 2.0 & 0.19 & 0.20 & 30. & 0 & 0 \\
\hline 2225 & 226 & B.227 & B. 2 & B. B.229 & B & B.231 & $B-23$ \\
\hline 0 & 0.0624 & 4.0936 & 72.1930 & 0.2 .6394 & 0.5094 & 0 & 0 \\
\hline B. 233 & 8.234 & B. 235 & B. 236 & B. 237 & B. 238 & \begin{tabular}{|l|l} 
\\
\end{tabular} & B. 24 \\
\hline 0 & 0.2442 & 18.5546 & 2.6894 & 3.1380 & 0.8170 & 0.0158 & 0 \\
\hline 241 & B.242 & B243 & B-244 & B- 245 & B.246 & B. 247 & B. 248 \\
\hline 0 & 0.2250 & 0.0240 & 0.6428 & 2.1268 & 0.1830 & 0 & \\
\hline 249 & B 25C & B-251 & B.252 & B 253 & B. 254 & $B 25$ & \\
\hline 0 & 0 & 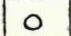 & & & & & \\
\hline
\end{tabular}

Third layer: $24 " 36^{\prime \prime}$

\begin{tabular}{|c|c|c|c|c|c|c|c|}
\hline 3-193 & B.194 & B-195 & B. 196 & B.197 & B. 198 & B. 199 & B.2O \\
\hline 201 & B. 202 & B. 203 & B. 204 & B-205 & B.206 & B-207 & B.20 \\
\hline & & 0 & & 0 & 0 & 0 & $\mathrm{O}$ \\
\hline 209 & B-210 & 211 & 212 & 213 & B.214 & B.215 & B-21 \\
\hline 0 & 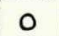 & 1. & & 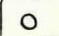 & 04208 & 0 & 0 \\
\hline 217 & B-218 & B.219 & $B-220$ & B-221 & B. 222 & B. 223 & $B-22$ \\
\hline & & & & 0 & 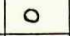 & o & o \\
\hline 225 & B-226 & 27 & B.228 & B.22 & B.230 & B.231 & B.29 \\
\hline 0 & & .0700 & 0.2616 & 0 & & 0 & 0 \\
\hline 33 & B-234 & B.235 & $\overline{36}$ & B 237 & B-2? & B.239 & B. 24 \\
\hline 0 & 0 & 0.0574 & 0.1184 & 0110 & 0.0230 & 0 & o \\
\hline 241 & B. 242 & B. 243 & B-244 & B. 245 & B. 246 & B. 247 & B. 248 \\
\hline & $c$ & & & & & 0 & o \\
\hline & 3.250 & B.251 & B.252 & B.253 & B.254 & B.255 & B 25 \\
\hline s & 0 & 0 & 0 & o & c & 0 & 0 \\
\hline
\end{tabular}

Second layer: $12^{*}=24^{*}$

\begin{tabular}{|c|c|c|c|c|c|c|c|}
\hline $\begin{array}{l}3.193 \\
0\end{array}$ & $\begin{array}{c}\text { B. } 194 \\
0\end{array}$ & $\begin{array}{c}\text { B } 195 \\
0\end{array}$ & $\begin{array}{c}\text { B.196 } \\
0\end{array}$ & $\begin{array}{c}B 197 \\
0\end{array}$ & \begin{tabular}{c|} 
B.198 \\
O
\end{tabular} & \begin{tabular}{c|} 
B-199 \\
0
\end{tabular} & $\begin{array}{c}\text { B.200 } \\
0\end{array}$ \\
\hline 8.201 & B. 202 & B.203 & B.204 & B.205 & B.206 & B-207 & B-208 \\
\hline 0 & 0 & 0 & 0 & 0 & 0 & 0 & 0 \\
\hline $3-209$ & B.210 & $B \cdot 211$ & B. 212 & B.213 & B-214 & B-215 & B. 21 \\
\hline 0 & 0 & 0 & 0 & 0 & 0 & 0 & 10 \\
\hline B.217 & B. 218 & B.219 & B. 220 & B. 221 & B.222 & B.223 & B-22 \\
\hline 0 & 0 & 0.1148 & 0.0560 & 0.0537 & 0 & 0 & 0 \\
\hline 3.225 & B. 226 & B. 227 & B 228 & B. 229 & B. 230 & B 23 & B. 23 \\
\hline 0 & 0 & 0.0192 & 3.7660 & 0 & 0.3192 & 0 & 0 \\
\hline B-233 & B. 234 & B.235 & B. 236 & B. 237 & B. 238 & B. 23 & B. 24 \\
\hline 0 & 0 & 0.0464 & 40.3100 & 0.3282 & 0.1810 & 0.0346 & 0 \\
\hline 3.211 & B. 242 & B.243 & B. 244 & 245 & B. 246 & B. 24 & B.24 \\
\hline 0 & 0 & O & 0 & 0.3236 & 0 & 0 & 0 \\
\hline 249 & B. 250 & B.251 & B. 252 & B. 253 & B.254 & B- 25 & B-256 \\
\hline$c$ & 10 & 0 & 0 & & & & \\
\hline
\end{tabular}

Fourth layer: $36=48 "$

\begin{tabular}{|c|c|c|c|c|c|c|c|}
\hline $\begin{array}{l}3193 \\
0\end{array}$ & $\begin{array}{c}\text { B.194 } \\
0\end{array}$ & $\begin{array}{c}\text { B-195 } \\
0\end{array}$ & $\begin{array}{c}\text { B.196 } \\
\text { O }\end{array}$ & $\begin{array}{c}B \cdot 197 \\
0\end{array}$ & $\begin{array}{c}\text { B. } 198 \\
\text { O }\end{array}$ & $\begin{array}{c}\text { B } 199 \\
\text { O }\end{array}$ & $\begin{array}{c}\text { B. } 200 \\
0\end{array}$ \\
\hline 201 & B-202 & $\mathrm{BZ} 03$ & B.204 & B-205 & B-206 & B 207 & B. 20 \\
\hline 0 & 0 & 0 & 0 & 0 & 0 & 0 & \\
\hline 8.209 & B-210 & B-211 & B.212 & B 213 & B. 214 & B.215 & B. 21 \\
\hline 0 & 0 & 은 & 0 & 응 & 0 & 0 & $\underline{\underline{\sigma}}$ \\
\hline B-217 & B.218 & B.219 & B.220 & B.221 & B.222 & $B-22$ & B 22 \\
\hline 은 & 0 & 0 & 으 & 0 & 오 & 0 & 0 \\
\hline 8225 & B. 226 & B.227 & B.228 & B 229 & B. 230 & B. 231 & B 23? \\
\hline 0 & 0 & 0 & 0 & 0 & 0 & 0 & 0 \\
\hline B.233 & B.234 & B.235 & B.236 & B.237 & B. 238 & B. 239 & B-24 \\
\hline 0 & 0 & 0 & 0 & 0 & 0 & 은 & 은 \\
\hline B. 241 & B. 242 & B. 243 & B-2.244 & B 245 & B. 246 & B. 247 & B. 248 \\
\hline 으 & 0 & o & 0 & 0 & 0 & 0 & \\
\hline 249 & B. 250 & B. 251 & B-252 & B- 253 & B. 254 & B-255 & B-256 \\
\hline 0 & 0 & 0 & 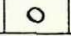 & 0 & O & & \\
\hline
\end{tabular}

B- $196=$ block number $; 0.0023=$ dry weight in qrams of roots in one cubic foot of soil; - location of tree trunk; $0=$ blocks without roots

Diagram indicating dry weight of roots per cubic foot of soil excavated in each layer of tree 4 : 
Tree no.5

First layer: 0"12"

\begin{tabular}{|l|l|l|l|l|l|l|l|}
\hline B. 257 & B. 258 & B. 259 & B. 260 & B. 261 & B.262 & B. 263 & B.264 \\
\hline
\end{tabular} \begin{tabular}{llllllllllllll}
\hline & 0 & 0 & 0.0444 & 0 & 0148 & $O$ & 0 & 0138 & 0.0094 & 0.0064 \\
\hline
\end{tabular} \begin{tabular}{|l|l|l|l|l|l|l|l|}
\hline B.265 & B266 & B 267 & B 268 & B 269 & B 270 & B 271 & B 272 \\
\hline
\end{tabular}

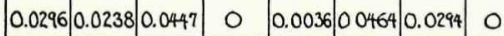
\begin{tabular}{|l|l|l|l|l|l|l|l|}
\hline B.273 & B.274 & B.275 & $\bar{B} 2.76$ & B.277 & B. 278 & B 279 & B 280 \\
\hline
\end{tabular} \begin{tabular}{lllllllllll}
0.1732 & 0.1060 & $O$ & 0.0792 & 0.7319 & 0 & 0 & 0 \\
\hline
\end{tabular}

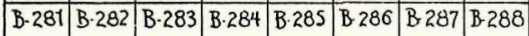

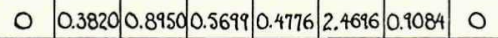

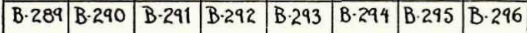
$\begin{array}{llllllllllll}0.7936 & 0.9804 & 2.0512 & 7.9846 & 4.1830 & 4.6524 & 0.6710 & O\end{array}$ \begin{tabular}{|l|l|l|l|l|l|l|l|l|l|l|l|l|l}
\hline B.297 & B.298 & B.299 & B 300 & B. 301 & B. 302 & B. 303 & B. 304 \\
\hline
\end{tabular} $\begin{array}{llllllllllll}1.0338 & 1.8522 & 8.4340 & 73.9154 & 29.2416 & 3.2820 & O & O\end{array}$ \begin{tabular}{|l|l|l|l|l|l|l|l|}
\hline B.3 305 & B 306 & B 307 & B. 308 & B. 309 & B-310 & B-311 & B-312 \\
\hline
\end{tabular} \begin{tabular}{llllllllllll}
1.6272 & 2.4431 & 0.9932 & 5.4614 & 8.0790 & 2.9224 & 0.1464 & 0.4854 \\
\hline
\end{tabular}

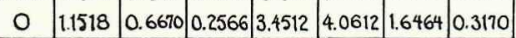

Third layer : 24:36"

\begin{tabular}{|c|c|c|c|c|c|c|c|}
\hline 257 & -258 & B. 2 & 6 & 26 & B. 262 & 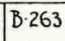 & \\
\hline 0 & 0 & 0 & o & 0 & 0 & 0 & 0 \\
\hline 265 & B.266 & B. 267 & B. 268 & B-269 & B. $27 \mathrm{C}$ & B-271 & B-27 \\
\hline 0 & 0 & & & & 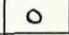 & 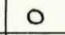 & \\
\hline 73 & & 15 & B-276 & 277 & 78 & $8.2 t$ & B-28 \\
\hline & & & & & & 0 & \\
\hline 281 & B. 282 & B.283 & B 284 & 285 & B.286 & B-287 & B-28 \\
\hline 0 & & & & & & 0 & \\
\hline 889 & B. 290 & B.291 & 99 & 293 & 94 & 295 & \\
\hline 0 & 0 & 0 & 0.0500 & 54 & 0 & 은 & \\
\hline & B.2298 & B.299 & B.300 & B-301 & B-302 & B. 303 & B-3 \\
\hline & & & 0.1 & 0.3220 & & 0 & \\
\hline 05 & B.306 & B. 307 & B. 308 & B. 309 & B. 310 & B-311 & B. \\
\hline & & & 0 & 0 & & 0 & \\
\hline & & & 316 & 317 & $B-318$ & B-319 & \\
\hline & & & & & & & \\
\hline
\end{tabular}
\begin{tabular}{|l|l|l|l|l|l|l|l|}
\hline B. 313 & B. 314 & B. 315 & B. 316 & B. 317 & B-318 & B-319 & B-320 \\
\hline
\end{tabular}

Second layer: $12^{-2} 24^{\circ}$

\begin{tabular}{|l|l|l|l|l|l|l|l|}
\hline B. 257 & B 258 & B 259 & B-260 & B.261 & B.262 & B.263 & B.264 \\
\hline
\end{tabular}

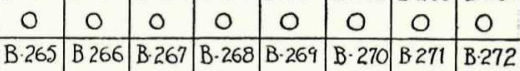
\begin{tabular}{c|c|c|c|c|c|c|c|}
\hline & 0 & 0 & $O$ & $O$ & $O$ & $O$ & $O$ \\
\hline
\end{tabular} \begin{tabular}{|l|l|l|l|l|l|l|l|}
\hline B 273 & B. 274 & B.275 & B.276 & B.277 & B 278 & B 279 & B 280 \\
\hline
\end{tabular} \begin{tabular}{lllllllll} 
& 0 & 0 & $O$ & 0 & 0.1168 & 0 & 0 \\
\hline
\end{tabular} \begin{tabular}{|c|c|c|c|c|c|c|c|}
\hline B 281 & B-282 & B.283 & B 284 & B 285 & B 286 & B 287 & B 288 \\
\hline
\end{tabular}

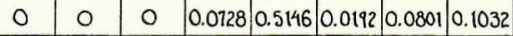
\begin{tabular}{|l|l|l|l|l|l|l|l|l|}
\hline B.289 & B.290 & B.291 & B.292 & B.293 & B.294 & B.295 & B 296 \\
\hline
\end{tabular} \begin{tabular}{lllllllllllllllll}
\hline & 0 & 0 & 0.9250 & 2.5664 & 0.8100 & 0.2902 & 0 & $O$ \\
\hline
\end{tabular} \begin{tabular}{|l|l|l|l|l|l|l|l|l|l|}
\hline B.2297 & B.298 & B.299 & B 300 & B 301 & B 302 & B. 303 & B. 304 \\
\hline
\end{tabular} $\begin{array}{llllllllll}O & 0 & 0.3488 & 5.3712 & 15020 & 0 & 0.3116 & O\end{array}$ \begin{tabular}{|l|l|l|l|l|l|l|l|}
\hline B. 305 & B-306 & B. 307 & B 308 & B. 309 & B.310 & B.311 & B.312 \\
\hline
\end{tabular} $\begin{array}{llllllllll}0 & 0 & 0.1104 & 0.7844 & 0.8648 & 0.4148 & 0.0761 & 0\end{array}$ \begin{tabular}{|l|l|l|l|l|l|l|l|}
\hline B-313 & B-314 & B-315 & B-316 & B-312 & B. 318 & B-319 & B-320 \\
\hline
\end{tabular} \begin{tabular}{lllllllllll}
\hline & 0 & 0 & $O$ & 0.1438 & 0.3762 & 0.2124 & 0 \\
\hline
\end{tabular}

Fourth layer: $36^{\prime \prime}-48$ "

\begin{tabular}{|c|c|c|c|c|c|c|c|}
\hline-257 & $\begin{array}{c}B \cdot 258 \\
0\end{array}$ & $\begin{array}{c}\text { B.259 } \\
0\end{array}$ & 260 & $B \cdot 261$ & 262 & 86 & 0 \\
\hline 265 & B.266 & B.267 & 268 & 269 & B.270 & B.271 & B.27 \\
\hline & & & & & & b & \\
\hline 73 & 14 & 15 & 6 & 277 & 278 & B.279 & $\mathrm{B}$. \\
\hline & & & & & & & \\
\hline 81 & 82 & B.283 & B. 284 & B.285 & B. 286 & B.287 & B. \\
\hline & & & & & 0 & & \\
\hline 289 & B-290 & B.291 & 92 & 13 & 94 & B & B-2 \\
\hline 0 & & $c$ & & & 0 & 0 & \\
\hline & B.298 & B-299 & 300 & B. 301 & B 30? & B. 30 & B. \\
\hline & & 0 & & & 0 & 0 & \\
\hline 05 & B. 300 & B.307 & 308 & B-309 & B. 310 & B. 311 & B. \\
\hline & 0 & 0 & & & 0 & 0 & \\
\hline & 3.314 & B 315 & B.316 & B.317 & B-318 & B.319 & $\mathrm{B} 3_{3}$ \\
\hline & & & & & & & \\
\hline
\end{tabular}

B-259= block number; $0.0444=$ dry weight in grams of roots in one cubic foot of soil;

- location of tree trunk; $O=$ blocks without roots

Diagram indicating dry weight of roots per cubic foot of soll excavated in each layer of tree 5 . 
Tree no.6

First layer: $0^{\prime \prime}-12^{*}$

\begin{tabular}{|c|c|c|c|c|c|c|c|}
\hline D.321 & B.322 & B. 323 & B.324 & B. 325 & B.326 & B.327 & B. 32 \\
\hline 0 & 0 & 0.0098 & 0.0078 & 0.6494 & 0.1392 & 0.0160 & 0.0315 \\
\hline B.32? & B. 330 & B. 331 & B. 332 & B. 333 & B. 334 & B. 335 & B. 336 \\
\hline 0 & 0 & 0 & 0 & 0 & 0.8162 & 0.0082 & 0 \\
\hline 3.337 & B. 338 & B-339 & B. 390 & B.341 & B. 342 & B. 343 & B. 344 \\
\hline 0 & 0 & 0 & 0 & 0 & 0 & 0 & 0 \\
\hline 3.345 & B 346 & B-347 & B-348 & B.349 & B- 350 & B. 351 & B. 352 \\
\hline 0 & 0 & 0 & 0.3830 & 1.2182 & 0.3182 & 0 & 0 \\
\hline 353 & B. 354 & B. 355 & B. 356 & B. 357 & B. 358 & B.359 & B. $36 C$ \\
\hline .1656 & 1.2126 & 0.3616 & 8.7864 & 3.2454 & 0.4760 & 0.7996 & 0 \\
\hline B. 361 & B. 362 & B. 363 & B. 364 & B. 365 & B. 366 & B 367 & B. 368 \\
\hline 0.0706 & $2.5303^{\circ}$ & 3.6772 & 82.53 & 84.90 & 6.4214 & 1.5778 & 0 \\
\hline B. 369 & B. 370 & B. 371 & B.372 & B 373 & B. 374 & B. 375 & B. 376 \\
\hline 0 & 0 & 1.3386 & 9.3220 & 9.4506 & 5.3974 & 0.1358 & 0 \\
\hline B. 377 & B. 378 & B. 379 & B-380 & B.381 & B. 382 & B. 383 & B-384 \\
\hline 1944 & 0 & 0 & 2.5728 & 0.1028 & 0.8676 & 0 & 0 \\
\hline
\end{tabular}

Third layer: $24^{4}-36 "$

\begin{tabular}{|c|c|c|c|c|c|c|c|}
\hline 321 & B.322 & B.323 & B-324 & B. 325 & B.326 & B. 327 & B.3 \\
\hline & 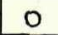 & 0 & 0 & 0 & 0 & 0 & \\
\hline 329 & $B 330$ & B-331 & B. 3332 & B-333 & B. 334 & B. 335 & $\sigma^{\circ}$ \\
\hline & & & 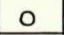 & 0 & & & \\
\hline 337 & B. 338 & B.339 & B. 340 & B. 341 & B. 342 & B. 343 & B.34 \\
\hline 0 & 0 & 0 & 0 & 0 & 0 & 은 & \\
\hline 345 & B. 346 & B. 347 & B. 348 & B. 349 & B. 350 & B. 351 & B. 35 \\
\hline 0 & 0 & 0 & 0 & & 0 & 0 & \\
\hline 53 & B. 354 & B. 355 & B. 356 & 357 & B.358 & B-359 & B. 36 \\
\hline 0 & 0 & 0 & 078 & 0.1207 & 0.1408 & 0 & \\
\hline 361 & B.362 & B. 363 & 369 & $B \cdot 365$ & B.366 & B-367 & $\mathrm{B} \cdot 3 \cdot \mathrm{G}$ \\
\hline 0 & 0 & 0.0262 & 1.3864 & 1.3996 & 0.2040 & 0 & \\
\hline 369 & B.370 & B. 371 & B.372 & B. 373 & B. 374 & $B \cdot 375$ & B. 376 \\
\hline 0 & 0 & 0.5400 & 1.1872 & 0.2168 & 0 & 0 & 0 \\
\hline & 6.3 & B 379 & & & 3.382 & b 38 & -38 \\
\hline & & & 0 & 0.0754 & & 0 & 0 \\
\hline
\end{tabular}

Second layer: 12"24"

\begin{tabular}{|c|c|c|c|c|c|c|c|}
\hline 321 & B. 322 & B. 323 & D. 324 & 2,3 & 10.5 & & \\
\hline 0 & 0 & 0 & 0 & 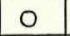 & 0 & 0 & \\
\hline 329 & B. 330 & B. 331 & B 332 & B. 333 & 8.334 & B. 335 & 33 \\
\hline & & & O & & & & \\
\hline 37 & 8 & 39 & 40 & 341 & 342 & B. 34: & \\
\hline & & & & & & & \\
\hline 345 & 8.346 & B.347 & 48 & B.349 & B. 350 & B. 351 & B. 3 \\
\hline & 0 & 0 & & 0 & 0 & 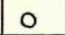 & \\
\hline 53 & B 354 & B. 355 & 56 & 357 & B. 358 & B.359 & \\
\hline 2392 & 0 & 0 & 0.1804 & 0.5814 & 0.1126 & O & \\
\hline 361 & 362 & & B. 364 & B. 365 & & & B.3 \\
\hline 0 & 0 & 1.0916 & 5698 & 5.7730 & 0.1908 & & \\
\hline 36 & B-370 & B.371 & B. 372 & B. 373 & B.374 & B. 375 & B. \\
\hline & 0 & & 10802 & 2.2860 & 0.0836 & 0 & \\
\hline & 18 & D" & B. 380 & B381 & B-38 & B. 383 & 38 \\
\hline & & & & 0 & 0 & 0 & \\
\hline
\end{tabular}

Fourth layer: $36 " 48^{\prime \prime}$

\begin{tabular}{|c|c|c|c|c|c|c|c|}
\hline 321 & 322 & $3 \cdot 323$ & 324 & B. 325 & B. 326 & D. 0 & \\
\hline 0 & 0 & ? & & 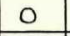 & 0 & 으 & \\
\hline 329 & B. 330 & B 331 & B.332 & B 333 & B. 334 & B.335 & \\
\hline & 0 & & ( & 0 & 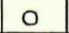 & 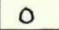 & \\
\hline 331 & B 338 & B. 339 & B. 340 & B.341 & B. 342 & B.343 & \\
\hline 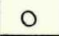 & 0 & 0 & 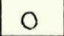 & 0 & 0 & 0 & \\
\hline 345 & B. 346 & B-347 & B. 348 & B.349 & B. 350 & B.351 & |D.3 \\
\hline 0 & 0 & & c & 0 & 0 & 0 & \\
\hline 353 & B. 354 & $B 355$ & B. 356 & B.357 & B. 358 & B.359 & $0 . x$ \\
\hline & 0 & U & of & 0 & 0 &  & \\
\hline 361 & B. 362 & B. 363 & B.364 & B. 365 & B. 366 & B.367 & \\
\hline & 0 & 8 & 으 & 0.0154 & 0 & 0 & \\
\hline 69 & B-370 & B.371 & B. 372 & B.373 & B 374 & B. 375 & B. \\
\hline 0 & 0 & & 0 & 0 & 0 & 0 & \\
\hline 377 & 378 & 379 & 380 & B.381 & 382 & B. 38 & 38 \\
\hline c & 0 & & & & & & \\
\hline
\end{tabular}

B-323 = block number; $0.0098=$ dry weight in grams of roots in one cubic foot of soll;

- location of tree trunk; $\mathrm{O}=$ blocks without roots.

Diagram indicaling dry weight of roots per cubic foot of soil excavated in each layer of tree 6 . 
As to planting system, the coffee seedlings should never be buried in the planting holes at time of planting. There is a tendency in the farmers to plant too deep which results in the tender new roots have to penetrate in hard, less fertile layers of soil affecting tremendously the rate and total amount of growth of the whole tree. The seedlings should be planted at the same level as that of the plants in the nursery, in this way all the good soil characteristics of the surface layers give the young seedlings better chances for a strong, vigorous development.

However, the root systems should be gradually induced to penetrate to deeper soil depths so that the roots may resist prolonged droughts, and absorb nutrients when the surface layers begin to get short of water and plant foods. This may be accomplished by making deep holes half way between the rows of trees in which to apply vegetable manures and chemical fertilizers. Such holes would in addition serve as deposits for fallen leaves and other plant débris.

In performing general agricultural operations, care should be taken to prune and mutilate the least number of roots by using proper tools and not operating too close to the tree trunks. This is possible by cultivating only in narrow strips half-way between the rows of trees. Recently vertical forks have been used successfully by numerous farmers because of their adaptability to loosen the soil breaking the least number of roots.

The coffee seedlings is susceptible to stagnant water, therefore, in soils with imperfect drainage, drainage ditchs should be provided in order to dispose of the excessive moisture.

The greatest concentration of roots being found at the top-most soil layer, fertilizer applications need not to be applied too deep. It is recommended to loosen the soil slightly under the drip of the trees and mix the fertilizer applied with the top soil and mulch. But on steep soils the fertilizer must be applied on the individual terraces or in shallow pits dug-out at the trunks in order to avoid washing of the fertilizer during heavy rainfall.

The better aeration of the surface layer is responsible to a certain extent for the greatest concentration of roots at the top-most 12 inches, therefore the soil of coffee plantations should be loosened to improve the aeration and consequently promote all the physical, chemical and biologic processes neessary for optimum root growth. 


\section{Summary}

1. The various methods used by Gómez (1) Lee (2) Lee and Bissinger (3), Nutman (4), (5), (6), Trench (7), Venkatraman (8), and Weaver and his associated (9), (10) for the study of the root system of plants have been described and discussed fully.

2. A new method developed by the writers has been described and used for the study of the root system of coffee, C. arabica L. in Puerto Rico. Briefly, this method consists in excavating the volume of soil assigned to each tree under study by blocks of one-cubic foot each and separating, drying and weighing the roots obtained from each block. By keeping an excavation map for the root system of the trees, the exact position of roots obtained for each block is obtained, therefore being possible to determine the quantity of roots present at the various soil levels excavated and the lateral spread of the roots as well.

3. Ninety-four percent of the coffee roots of all trees were found in the top-most 12 inches of soil.

4. The high percentage of organic matter in Coloso Clay, especially in the lop-most layers, and the better aeration at the surface, apparently accounted to a great extent for the presence of more roots in the top-most 12 inches of soil.

5. The imperfect drainage conditions existing at localities where Coloso Clay predominates affect the development of the root systems of coffee plants.

6. Coloso Clay is a productive soil when proper drainage conditions are provided and the principal plant foods are generally distributed uniformly to a depth of 48 inches.

7. A heavy and vigorous coffee tree top is not dependent on an extensive root system.

8. There is no fixed "(tops to roots) ratio" in coffee trees, but generally the ratio of tops to roots may be figured to be $8: 1$.

9. In selecting trees with vigorous, heavy tops and a strong, extensive root systems, the diameter of the trunk is a better indication of the possession of these characteristics than either the height or the lateral spread of the tree.

10. There was approximately 50 percent of water in the upright stems of coffee trees, 23 percent in the lateral branches and leaves, 39 percent in the whole tree tops and 50 percent in the roots. 
11. The absorbing area of the root system is not confined to definite places on the soil but is distributed thru-out all places penetrated by the main and secondary roots.

1.2. The vertical penetration of roots of 7-year-old trees is 3 feet and the lateral extension is 4 feet.

13. The results obtained have been discussed fully in relation to possible aplications in the performance of agricultural practices followed by farmers in coffee plantations.

\section{ACKNOWLEDGMENTS}

The writers are indebted to: Directors Atherton Lee, Fco. López Domínguez, Melville T. Cook and José I. Otero, Librarian, for their valuable suggestions and criticisms of the manuscript; to J. O. Carrero, for root weights and chemical analysis; to J. A. Bonnet for the physical analyses and classification of the soil type and to B. Alzamora for kindly permitting the use of the coffee farm of the College of Agriculture and Mechanic Arts, University of Puerto Rico for this study. 


\section{BIBLIOGRAPHY}

1. Gómez, L. A. Distribution of sugar cane roots in the soil in western Puerto Rico. Rev. Agri. Puerto Rico, Suppl. 1:14-25, 1936.

2. Lee, H. A. The distribution of roots of sugar cane in the soil in the Hawaiian Islands. Plant Physiol., 1:363-378, 1926.

3. Bissinger, G. H. The distribution of sugar cane roots in the soil on the Island of Luzon. Sugar News 9(5): $1-10,1928$.

4. Nutman, F. J. The root-system of $C$. arabica. Pt. I.-Rootsystems in typical soils of British East Africa. Empire Jour. Expt. Agric. 1(3) : 271-284, 1933.

5. effect of some soil conditions in modifying the normal root-system. Empire Journ. Exp. Agric. 1(4) : 285-296, 1933.

6. spatial distribution of the absorbing area of the root. Empire Jour. Expt. Agriculture: 2(8) : 294-302, 1934.

7. Trench, A. D. Preliminary observations on coffee roots in Kenya. Dept. Agric. Colony \& Protect. Kenya, Bull. 2, 10 p., 1934.

8. Venkatraman, T. S., \& Thomas, R. Simple contrivances for studying root development in agricultural crops. Agric. Jour. India $19: 509,1924$.

9. Weaver, J. E. The ecological relations of roots. Carnegie Inst. Washington Publ. 286, 128 p. 1919.

10. Weaver, J. E., \& Christ, J. W. Relation of hard-pan to root penetration in the Great Plain. Ecology, 3(3) :237-249, 1922.

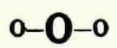

